\title{
Biocrude Oil Production by Integrating Microalgae Polyculture and Wastewater Treatment: Novel Proposal on the Use of Deep Water-Depth Polyculture of Mixotrophic Microalgae
}

\author{
Makoto M. Watanabe ${ }^{1,2, *}$ and Andreas Isdepsky ${ }^{1,2}$ \\ 1 MoBiol Technologies Corporation, 1155-50 Kakioka, Ishioka 315-0116, Ibaraki, Japan; andreas@mobiol.tech \\ 2 ABES, Faculty of Life and Environment Sciences, University of Tsukuba, 1-1-1 Tennodai, \\ Tsukuba 305-8572, Ibaraki, Japan \\ * Correspondence: watanabe.makoto.ga@u.tsukuba.ac.jp
}

check for updates

Citation: Watanabe, M.M.; Isdepsky, A. Biocrude Oil Production by Integrating Microalgae Polyculture and Wastewater Treatment: Novel Proposal on the Use of Deep Water-Depth Polyculture of Mixotrophic Microalgae. Energies 2021, 14, 6992. https://doi.org/ $10.3390 /$ en14216992

Academic Editor:

Alberto-Jesus Perea-Moreno

Received: 8 September 2021

Accepted: 20 October 2021

Published: 25 October 2021

Publisher's Note: MDPI stays neutral with regard to jurisdictional claims in published maps and institutional affiliations.

Copyright: (c) 2021 by the authors. Licensee MDPI, Basel, Switzerland. This article is an open access article distributed under the terms and conditions of the Creative Commons Attribution (CC BY) license (https:// creativecommons.org/licenses/by/ $4.0 /)$.

\begin{abstract}
Microalgae have attracted significant attention worldwide as one of the most promising feedstock fossil fuel alternatives. However, there are a few challenges for algal fuels to compete with fossil fuels that need to be addressed. Therefore, this study reviews the R\&D status of microalgaebased polyculture and biocrude oil production, along with wastewater treatment. Mixotrophic algae are free to some extent from light restrictions using organic matter and have the ability to grow well even in deep water-depth cultivation. It is proposed that integrating the mixotrophic microalgae polyculture and wastewater treatment process is the most promising and harmonizing means to simultaneously increase capacities of microalgae biomass production and wastewater treatment with a low land footprint and high robustness to perturbations. A large amount of mixotrophic algae biomass is harvested, concentrated, and dewatered by combining highly efficient sedimentation through flocculation and energy efficient filtration, which reduce the carbon footprint for algae fuel production and coincide with the subsequent hydrothermal liquefaction (HTL) conversion. HTL products are obtained with a relatively low carbon footprint and separated into biocrude oil, solid, aqueous, and gas fractions. Algae biomass feedstock-based HTL conversion has a high biocrude oil yield and quality available for existing oil refineries; it also has a bioavailability of the recycled nitrogen and phosphorus from the aqueous phase of algae community HTL. The HTL biocrude oil represents higher sustainability than conventional liquid fuels and other biofuels for the combination of greenhouse gas (GHG) and energy return on investment (EROI). Deep water-depth polyculture of mixotrophic microalgae using sewage has a high potential to produce sustainable biocrude oil within the land area of existing sewage treatment plants in Japan to fulfill imported crude oil.
\end{abstract}

Keywords: mixotrophic algae; polyculture; wastewater treatment; HTL; biocrude; nutrient recovery

\section{Introduction}

As a true alternative to fossil fuels, an ideal organism produced in large quantities of 4,474,330,000 tons worldwide must have at least 12 requirements (Table 1). 
Table 1. Requirement for an ideal organism as an alternative feedstock to fossil fuels (prepared in reference of [1-3]).

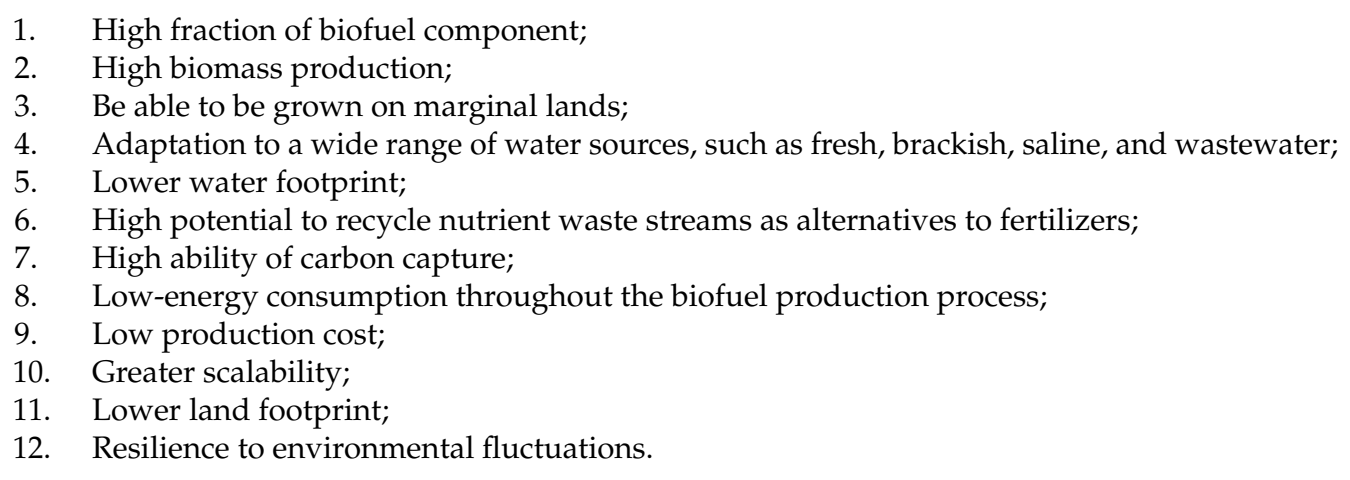

Land plants and algae, which are principally photosynthetic organisms, have attracted significant attention worldwide as promising feedstocks for future fossil fuel alternatives. However, whether edible or inedible, land plants require arable land concomitant with a large amount of freshwater resources and have relatively low lipid productivity for biodiesel production. Thus, they lack in sustainability for requirements (1), (3), (4), (5), (6), (11), and (12) in Table 1. Microalgae potentially have more advantages than land plants for requirement (1) to (7). According to model analysis on wastewater treatment by algae, the production cost of algae oil is lower than that of fossil fuels by simultaneously achieving algae biomass production and sewage purification [3]. Microalgae have a high potential to produce biofuel with a much lower land footprint than land plants due to their high oil yield capacity. However, photosynthetic microalgae must be cultured at a shallow water depth $(<0.2 \mathrm{~m})$ to avoid impairing light utilization efficiency. It means that microalgae with high biomass production (assuming 100 tons.ha ${ }^{-1} \cdot$ year $^{-1}$ and $50 \%$ oil content), 2.8 million ha is required for the actual cultivation area alone to cover Japanese crude oil imports $\left(0.13 \times 10^{9}\right.$ tons year $^{-1}$ in 2020). In contrast, the total area of sewage treatment plants in Japan is 1.37 million ha, and it is necessary to increase the algae biomass productivity per land area to achieve the Japanese demand for crude oil by using the existing footprint of sewage treatment plants. Additionally, microalgae have some issues for the future commercial application in reference to requirements (8), (9), (11), and (12), such as a lower energy return on investment (EROI) and higher biomass production cost than land plants, the necessity for a large land area, and vulnerability to environmental and biological stresses, which should be solved for future use as an alternative to fossil fuel. In particular, the traditional lipid extraction-transesterification method for producing biofuel from lipid rich microalgae is energy intensive because it requires the drying of cultured microalgae. Hydrothermal liquefaction (HTL) of biomass into biofuel has attracted significant attention as a solution to serious issues imposed by traditional methods. HTL is advantageous. The reason is that it uses wet biomass directly and converts the entire algae biomass to biocrude oil. However, the differences of biochemical composition combined with various optimal conditions make general prediction and operation of HTL difficult [4]. Additionally, developments on conventional HTL processes to increase EROI, lower capital and process costs, and accelerate $\mathrm{CO}_{2}$ reduction through technology innovation are needed [4-8]. The development of innovative HTL technology to solve these issues is steadily progressing $[4,9,10]$.

In many cases, monocultures of oil-rich and high-growth microalgae have been used for algal fuel production. However, good growth under optimal and suboptimal environmental conditions is limited by the tolerance level of the cultured species. Particularly in temperate regions, it is difficult to maintain monocultures of microalgae at high and stable algae production throughout the year due to large fluctuations in the annual temperature and solar radiation. In addition, microalgae monoculture is sometimes subjected to total 
algae biomass loss due to natural introduction of predator or pest species [11]. Therefore, it is difficult to establish a stable year-round biomass production without appropriate environmental controls using the monoculture concept in temperate regions. Temperate regions, occupying $10 \%$ of the earth and $30 \%$ of the land, are home to approximately half of the world's population and have high land-use rates, with various industries being constructed. Thus, energy production in temperate regions is essential when considering global and national energy security. Microalgae biomass production in monoculture is more costly and energy-intensive than terrestrial energy crop production [12,13]. For these reasons, it is necessary to develop technology to produce stable algae-based fuels throughout the year in temperate regions with large environmental fluctuations and limited land area to make them competitive with fossil fuels [14].

The polyculture of native microalgae communities is more suitable for large-scale biomass production and has several advantages compared with monocultures of specific strains [11,15]:

1. stable culture and production because of the mixed component of algae with diverse of tolerance levels and the absence of pond crash;

2. the efficient use of resources (nutrients) by niche complementarity;

3. cheap and easy operation and maintenance.

The cultivaton of native algal communities has been effectively used for wastewater treatment in open ponds [16-20]. The Look Back at the US Department of Energy's (DOE's) Aquatic Species Program [21] recommended the development and demostration of microalgae biodiesel production as part of a wastewater treatment process. A subsequent model study in this field of research showed that when the primary process objective was wastewater treatment with biofuels as a byproduct, bio-oil production cost in 100 ha area was estimated to be approximately one-third of petroleum oil prices [3]. It was first reported that wastewater treatment by microalgae could reduce the cost of biofuel production. Therefore, it is necessary to demonstrate and verify this model at the scale of a conventional waterwater treatment plant.

The performance of the microalgae-based wastewater treatment process is mainly a function of algal production and wastewater treatment capacities. When using photosynthetic microalgae, the culture depth should be shorter to secure higher average irradiance for algal photosynthesis, resulting in high algal production and nutrient recovery. However, a shorter culture depth decreases the amount of wastewater treated per surface unit; thus, the algae-based wastewater treatment process requires a larger area than the conventional wastewater treatment process [22,23], resulting in a large land footprint. Therefore, it is necessary to propose a method to solve this dilemma.

This study reviews the R\&D status of algae-based polyculture and biocrude oil production using wastewater with special reference to sewage treatment, which is attracting significant attention as it corresponds to most of the above ideal conditions. Sewage containing organic and inorganic pollutants, such as biological oxygen demand (BOD) components, nitrogen, and phosphorus, is an excellent source of nutrients for mixotrophic microalgae. Consequently, mixotrophic microalgae can be expected to purify the sewage to meet the quality standards of discharge water established in each country, resulting in high nutrient recovery. We also highlight the appropriate concentration and dewatering methods eligible for the subsequent HTL biocrude oil conversion and reasonable algal biofuel life cycle assessments. Since microalgae polyculture grown using sewage may sometimes be low in lipid content [14], an HTL method that converts the entire algae biomass into biocrude oil under high temperature and pressure should be employed. As HTL facilitates the conversion of the entire fraction of lipids, proteins, and carbohydrates to biocrude oil, it is unnecessary to promote lipid accumulation and extract the lipids. The essential factors for the efficient production of HTL biocrude oil are the need for stable and high algal biomass production. The overall economics for the HTL algal pathway are more strongly influenced by improvements in algae biomass productivity [24]. Therefore, the 
appropriate concentration and dewatering methods for the optimization of the conversion process and biocrude-oil quality should be considered.

This study proposes a considerable improvement on the upstream process, the best selection of an appropriate concentration, and the advantages and usefulness of biocrudeoil production through HTL from wastewater-grown algae polyculture. The realistic view of its amount of land use highlights the recent deep water-depth polyculture of mixotrophic microalgae combined with wastewater treatment process. This suggests that it is the most promising way to simultaneously increase capacities of algal biomass production, achieving wastewater treatment with high perturbation resilience and biocrude oil production, showing a high potential to meet the current demand of crude oil in Japan [14,25-28].

\section{Wastewater in the World and Japan}

Global freshwater withdrawals are estimated to be $3928 \mathrm{~km}^{3} \cdot \mathrm{year}^{-1}, 56 \%$ of which is released into the environment as wastewater as municipal and industrial effluent and agricultural drainage water [29]. On average, high-income countries treat $70 \%$ of wastewater; however, the ratio drops to $38 \%, 28 \%$, and $8 \%$ in upper-middle-income, lower-middleincome, and low-income countries, respectively [30]. These estimates support the suggestion that more than $80 \%$ of wastewater is released into the environment without adequate treatment [31].

In Japan, the annual sewage treatment is 15.4 billion $\mathrm{m}^{3}$ in a total area of 1.37 million ha. Assuming three cases of $10,000,50,000$, and $100,000 \mathrm{~m}^{3}$ as the maximum daily inflow of sewage water, operation/maintenance costs and energy consumption per unit $\left(\mathrm{m}^{3}\right)$ are estimated to be $27-13 \mathrm{JPY} \cdot \mathrm{m}^{-3}$ and $3.02-1.76 \mathrm{MJ} \cdot \mathrm{m}^{-3}$, respectively, using the conventional activated sludge process and $32-17 \mathrm{JPY} \cdot \mathrm{m}^{-3}$ and $3.86-1.87 \mathrm{MJ} \cdot \mathrm{m}^{-3}$, respectively, using the advanced anaerobic-anoxic-oxic process (Table 2) [32].

Table 2. Estimation of construction and operation/maintenance fees and unit energy consumption of conventional activated sludge process and advanced anaerobic-anoxic-oxic process (excluding incinerator) [32].

\begin{tabular}{|c|c|c|c|}
\hline Daily Maximum Inflow of Sewage & $10,000 \mathrm{~m}^{3} \cdot$ day $^{-1}$ & $50,000 \mathrm{~m}^{3} \cdot \mathrm{day}^{-1}$ & $100,000 \mathrm{~m}^{3} \cdot \mathrm{day}^{-1}$ \\
\hline \multicolumn{4}{|l|}{ Conventional activated sludge process } \\
\hline Construction fee (million JPY) & 6374 & 16,212 & 24,235 \\
\hline Unit construction fee $\left(\right.$ million JPY $\left.\cdot \mathrm{m}^{-3}\right)$ & 0.64 & 0.32 & 0.24 \\
\hline Operation/maintenance fee (million JPY·year ${ }^{-1}$ ) & 100 & 302 & 488 \\
\hline Unit operation/maintenance fee $\left(\mathrm{JPY} \cdot \mathrm{m}^{-3} \cdot \mathrm{day}^{-1}\right)$ & 27 & 17 & 13 \\
\hline Energy consumption $\left(\mathrm{MJ} \cdot \mathrm{day}^{-1}\right)$ & 30,178 & 106,960 & 175,472 \\
\hline Unit energy consumption $\left(\mathrm{MJ} \cdot \mathrm{m}^{-3}\right)$ & 3.02 & 2.14 & 1.76 \\
\hline \multicolumn{4}{|l|}{ Anaerobic-anoxic-oxic (A2O) process } \\
\hline Construction fee (million JPY) & 7329 & 19,642 & 29,979 \\
\hline Unit construction fee $\left(\right.$ million JPY $\left.\cdot \mathrm{m}^{-3}\right)$ & 0.73 & 0.39 & 0.30 \\
\hline Operation/maintenance fee (million JPY·year ${ }^{-1}$ ) & 116 & 371 & 611 \\
\hline Unit operation/maintenance fee $\left(\mathrm{JPY} \cdot \mathrm{m}^{-3} \cdot \mathrm{day}^{-1}\right)$ & 32 & 20 & 17 \\
\hline Energy consumption $\left(\mathrm{MJ} \cdot \mathrm{day}^{-1}\right)$ & 38,582 & 116,510 & 187,180 \\
\hline Unit energy consumption $\left(\mathrm{MJ} \cdot \mathrm{m}^{-3}\right)$ & 3.86 & 2.33 & 1.87 \\
\hline
\end{tabular}

In the conventional activated sludge process, a $1 \mathrm{~kg}$ chemical oxygen demand (COD) reduction produces 0.3 to $0.5 \mathrm{~kg}$ of dry-weight secondary sludge, and $0.78 \mathrm{~kg} \mathrm{CO}_{2}-\mathrm{e} \cdot \mathrm{m}^{-3}$ is discharged during the sludge treatment process [33]. The greenhouse gas (GHG) emissions during sewage treatment are estimated to be $3 \%$ of global GHG emissions [34]. In Japan, the annual GHG equivalent to 6.95 million tons of $\mathrm{CO}_{2}$ is emitted during the sewage treatment, accounting for approximately $0.5 \%$ of total $\mathrm{CO}_{2}$ emissions [35]. The blower used on the activated sludge treatment consumes most of power consumed during water treatment. Approximately $24 \%$ of excess sewage sludge is recovered for energy generation, 
such as methane production, and $10 \%$ is recovered as fertilizer on green farmland. The remaining sewage sludge is incinerated to generate $\mathrm{N}_{2} \mathrm{O}$ in the process, which accounts for $24 \%$ of GHG emissions in sewage treatment [36]. In addition, to avoid the worst scenario of phosphate ore depletion by 2060 [37], it is necessary to recover phosphorus from wastewater and waste. Approximately $10 \%$ of phosphorus imported in Japan flows into the sewerage system, of which only about $10 \%$ is used as compost [38]. The main commercial processes for removing and recovering phosphorus from wastewater effluents, such as chemical precipitation with iron, alum, or lime, is required. However, this process requires further refining, fine-tuning, and optimization. It renders the precipitates difficult, if not impossible, to recycle in an economical industrial manner [39]. Thus, the algal accumulation of phosphates has been extensively studied to evaluate their sustainable use of phosphates $[39,40]$.

There are advancements in wastewater treatment, such as anaerobic treatment, membrane reactors, microbial fuel cells (MFCs), and anammox technology. However, they have advantages and disadvantages. Anaerobic treatment is used in the current wastewater treatment; however, it consumes twice as much energy as an aerobic treatment [41] and requires a prolonged hydraulic retention time [42,43]. Membrane reactors are fundamentally based on anaerobic technology, offering quicker start-up times, shorter retention times, and better COD removal; however, it causes the dissolution of methane in treated water and fouling in the reactor [33]. The COD removal efficiency of MFCs ranges above 50\%; however, it is lower than anaerobic treatment $[44,45]$. Anammox treatment reduces the COD by $90 \%$ or more and $\mathrm{CO}_{2}$ emissions by $60 \%$ or more [46]. However, the anammox reaction requires further treatment to reduce the nitrogen due to the production of a certain amount of nitrate as a by-product. Optimal control technology for nitrate reduction by denitrifying bacteria (heterotrophic bacteria) and ammonia oxidation by anammox bacteria (autotrophic bacteria) is required for practical use. Overall, the above advanced technologies cannot treat and recover phosphorus. Considering the need for energy-efficient blowers, sludge reduction, and phosphorus recovery, as well as the ability of algae to purify sewage, which has been demonstrated in recent years, it is necessary to consider the introduction of algae for wastewater treatment.

\section{Algae Biomass Production and Wastewater Treatment}

Many authors have supported integrating wastewater treatment and algae biomass production $[3,47,48]$. Multiple benefits include the circular use of freshwater by purifying sewage, thus reducing the cost of biofuel production, creating and increasing market value for non-portable water supplies, and reducing the impact of contaminated water on the living environment and ecosystems [11]. According to model analysis, the algae oil production cost is less than USD $0.18 \cdot \mathrm{L}^{-1}$ oil, significantly lower than that of fossil fuels; algae biomass production cost can be reduced to be less than EUR $1 \mathrm{~kg}^{-1}$ dry-algae by simultaneously achieving algae-based oil or algae biomass production and sewage purification $[3,23]$. Thus, research on optimal integrated technology for algal biomass production and sewage treatment have been extensively conducted to verify this model $[43,49,50]$. In this study, we focus on achieving the ideal algae fuel production as an alternative to fossil fuels.

\subsection{Mixotrophic Algae}

There are three nutritional modes in microalgae: photo-autotrophic (photosynthesis), heterotrophic, and mixotrophic, a combination of the first two modes. Thus, mixotrophic algae are less light restricted using organic matter and can grow well even in deep waterdepth cultivation [14]. In the algae polyculture on wastewater, the mixotrophic microalgae community contributes exceedingly to the overall algae biomass production and sewage treatment and purification. Wastewater, containing organic and inorganic pollutants, such as BOD, nitrogen, and phosphorus, is an excellent source of nutrients for mixotrophic microalgae. 
It has been emphasized that heterotrophic and mixotrophic microalgae can assimilate only low-molecular-weight compounds, such as glucose and glycerol; thus, it cannot be assumed that mixotrophic microalgae can degrade and use large organic compounds [23]. However, it has been revealed that marine coccolithophores and freshwater mixotrophic microalgae strains of Scenedesmus and Chlorella could use a wide range of organic substrates, such as carbohydrates, carboxylic acids, amino acids, amines, phenolic compounds, and polymers [51,52]. In addition, diverse organic substrates such as monosodium glutamate wastewater, cheese whey permeate, and fruit peel have been successfully used for mixotrophic microalgae growth [53-56]. Thus, mixotrophic microalgae play a significant role in reducing $\mathrm{COD} / \mathrm{BOD}$ in wastewater such as heterotrophic microbes; they also have a high potential for biomass and biofuel production using organic wastewater, which is an anthropogenic GHG source.

A field experiment demonstrated that mixotrophic microalgae biomass productivity possibly exceeded the sum of potential photoautotrophic and heterotrophic productivities of the microalgae [14]. This suggests that the mixotrophic growth is not a simple combination of photoautotrophic and heterotrophic growth, as it has been extensively reported previously in laboratory studies $[53,57,58]$. Acetate can be metabolized by algal cells via acetyl-coA to produce $2 \mathrm{CO}_{2}$ in the tricarboxylic acid cycle [59], possibly stimulating photoautotrophic growth, as supposed in glucose-based mixotrophy [57]. Thus, the field investigation by Demura et al. [14] provided a feasible carbon mass balance to understand the roles of photosynthesis and organic compounds in mixotrophy.

Considering the need for a $\mathrm{CO}_{2}$ supply to enhance the photosynthetic algae, sourcing $\mathrm{CO}_{2}$ from co-located power plants and other sources introduces several technical, logistical, and scalable challenges. It could significantly hinder the practical deployment of algae culture farms in supporting fuel outputs. In addition, flue gas carbon capture and transport from point-source are very expensive and energy-intensive to enable either cost or sustainability goals for algae-based biofuel production [60]. Mixotrophic microalgae may have a high potential for solving the above bottlenecks of $\mathrm{CO}_{2}$ supply because they can utilize both atmospheric $\mathrm{CO}_{2}$ and organic carbon as a carbon source.

\subsection{Polyculture}

Numerous reports have demonstrated the importance of species or functional group diversity in terms of community stability and ecosystem function. Diverse communities in terrestrial and aquatic environments tend to be more resilient and resistant to perturbations due to different mechanisms, such as niche complementarity, niche differentiation, and functional redundancy [61-66]. Dzialowski and Smith [62] suggested that monocultures could be inherently unstable as many interactions are possible due to unoccupied niches. Polycultures are probably more robust to diverse perturbations because complex communities contain organisms with inherent resistance to specific optimization and various ranges of ecological and physiological resistances $[67,68]$. Behl et al. [69] found a positive correlation between species diversity and biomass yields in all phytoplankton. Considerable numbers of polyculture studies of microalgae have been conducted (Table 3). Most of the studies strongly suggested that polyculture outperforms the best mono-culture by performing multiple functions simultaneously, such as producing resilient communities, enabling efficient nutrient uptake and resisting population crashes and undesirable invaded species, and showing less tendency to trade-off between desirable functions [70-75], and only few reports indicated that polyculture does not outperfor $\mathrm{m}$ the most pro-ductive monoculture in producing biocrude oil [71] and biomass [72]. 
Table 3. Polyculture performances for biomass production, nutrient use and removal, and biocrude production.

\begin{tabular}{|c|c|c|c|}
\hline Culture & Conditions & Results Highlighted & Ref. \\
\hline Natural algal polyculture & $\begin{array}{l}5 \text { ha demonstration HRAP } \\
\text { system treating primary } \\
\text { settled wastewater. } \\
15 \text { month operation. }\end{array}$ & $\begin{array}{l}\text { - Nutrient removal: about } 87 \% \text { removal of fBOD, about } \\
65 \% \text { removal of } \mathrm{NH}_{4}-\mathrm{N} \text {, about } 19 \% \text { removal of DRP and } \\
\text { about } 2 \text { log removal of Escherichia coli. } \\
\text { - Algal/bacterial biomass productivity: about } \\
8 \mathrm{~g} \cdot \mathrm{m}^{-2} \cdot \text { day }^{-1} \text {. } \\
\text { - Conversion efficiency to biocrude oil: about } 30 \% \text {. }\end{array}$ & [16] \\
\hline
\end{tabular}

\begin{tabular}{lll}
\hline Natural algal polyculture & $\begin{array}{l}5 \text { ha demonstration HRAP } \\
\text { system treating primary } \\
\text { settled wastewater. }\end{array}$ & See Table 4 in the present paper \\
& $\begin{array}{l}\text { Three HRAP pond depths } \\
(20,30 \text { and } 40 \mathrm{~cm}) \text { treating } \\
\text { primary settled wastewater. }\end{array}$ & $\begin{array}{l}\text { Productivity: Areal productivity ranged from } 134 \text { to } \\
\text { depth. }\end{array}$ \\
- Nutrient uptake: Microalgae in the $40 \mathrm{~cm}$ depth were \\
more efficient at $\mathrm{NH}_{4}-\mathrm{N}$ uptake than those in the $20 \mathrm{~cm}$ \\
depth.
\end{tabular}

- Species richness produces resilient communities, enabling efficient nutrient uptake due to niche complementarity.

Offshore photobioreactor.

Natural algal polyculture Liquid (wastewater) depth ranged from 5 to $25 \mathrm{~cm}$.
- Productivity: 3.5 to $22.7 \mathrm{~g} \cdot \mathrm{m}^{-2} \cdot$ day $^{-1}$.

- Resulting biomass: suitable for HTL fuel conversion due to consistent lipid content $(13.0 \pm 2.5)$, low ash content $(12.0 \pm 2.1 \%)$, and consistent elemental composition (C: $49.6 \pm 1.1, \mathrm{H}: 7.2 \pm 0.2, \mathrm{~N}: 8.0 \pm 1.0, \mathrm{~S}$ : $0.9 \pm 0.1)$

- Polycultures does not outperform the best species in biocrude production but has stabilizing effects on biocrude oil production over time in the variable temperature environment.

Monoculture: six microalgae species Polyculture: two-species, four-species, and six-species
$10 \mathrm{~L}$ tank. Temperture: constant $\left(22^{\circ} \mathrm{C}\right)$ and variable $\left(17^{\circ} \mathrm{C}\right.$ to $\left.27^{\circ} \mathrm{C}\right)$.
- The two-species cultures produced biomass and biocrude of a quality that matched the average monoculture, while the four- and six-species cultures were worse on average.

- The polycultures may offer potentially compelling advantages, including higher lipid content and lower biocrude $\mathrm{N}$ and $\mathrm{O}$ content, over their monoculture counterparts. However, such advantages, will likely be found only on a combination-specific basis.

\section{Monoculture: five} microalgae species Polyculture: two-species, four-species, and six-species
9.5 L chemostat with $30 \%$ refresh of medium per week.
- Some polycultures exhibit more balanced performance and maintain all three functions of nitrogen- and phosporus-nutrient-use efficiencies, and biocrude productivity at a high level simultaneously than any of monocultures.
- Diversity potentially enhances the functions of biomass and biocrude-oil production and resistance against population crashes and invasions by unwanted species.

- Most diverse polyculture (four species) forms more functions at higher levels than any of monocultures.
Monoculture: five microalgae species Polyculture: two-species and four species
1100 L outdoor pond. 
Table 3. Cont.

Culture
Monoculture: five
microalgae species
Polyculture: two-species
and four-species.

Conditions

1100 L outdoor pond.

and four-species.

Mixed-culture microalgae

Directly harvested from wastewater treatment sysytem

Monoculture: Five microalgae species Polyculture: three-species, six-species, and a natural polyculture
Batch culture using flasks with anaerobic digester effluent.

\section{Results Highlighted}

- Some two-species cultures improved EROI and GHGs

by $20 \%$ and $16 \%$, respectively, compared to the best monoculture.

- Bicultures outperformed monocultures by performing multiple functions simultaneously (e.g., improved stability, nutrient efficiency, biocrude characteristics)
Maximum biocrude-oil yield: $49 \%$ of volatile matter (=25.7\% of dry weight).

Elemental composition of C, H, N, and O: 65.7, 8.76, 3.93, and 21.7.
- No polyculture exceeded the biomass of the most productive monoculture, but higher grazing resistance is observed among polycultures when exposed to grazing pressure.

- Polycultures may be less prone to trade-offs between desirable functions (like grazing resistance and growth rate).

- The HRAP with $20 \mathrm{~cm}$ of water depth had about $38 \%$ HRAP with different depths higher biomass productivity per unit area

Natural algal polyculture of 20,30 , and $40 \mathrm{~cm}$. $\left(6.16 \pm 0.33 \mathrm{~g} \cdot \mathrm{m}^{-2} \cdot \mathrm{day}^{-1}\right)$ and required lower nutrients and energy consumption than the other water depths.

- Ash content (dry wt.\%): 20.5.

- HTL biocrude oil productions (ash-free dry wt eq.): isolated

Photobioreactor with $37 \mathrm{~L}$ brackish dairy wastewater.

$11.7 \%$ to $30 \%$ of light oil and: $4 \%$ to $10 \%$ of heavy oil.
$300 \mathrm{~mL}$ conical flasks with primarily treated municipal wastewater.
- Polyculture with $\mathrm{CO}_{2}$ supply reduces nitrogen and phosphorus concentration by the level allowed by the EU Council Directive. microalgae species

Polyculture: three-species

Natural algal polyculture An assembled polyculture of three-species

Open raceway pond with anaerobic digester effluent.
- The natural polyculture: $25 \%$ higher biomass productivity and $19 \%$ higher N-removal efficiency than the assembled polyculture.

- Differences became even more pronounced under grazing and resource stress conditions.
HRAPs with and without - The HRAP without primary treatment had higher primarily treated water.

7.5 L phtobioreactor wth wastewater from the paper indusry.
Consortium of two algae and two bacteria species
Natural algal polyculture biodiversity and productivity.

- Biocrude oil yield: 15\%.

- Elemental composition of C,H,N,S and O: 63.16, 8.11, $5.37,0.21$ and 23.15 , similar to HTL biocrude oil of the microalgae monocultures.

- Areal productivity: $29.2 \mathrm{~g} \cdot \mathrm{m}^{-2} \cdot \mathrm{day}^{-1}$.

- Reduction of TN, TP, SS, and BOD below the levels of the quality standard of discharge water based on the Sewage Act in Japan.

Natural algal polyculture Outdoor vessel-type reactor with water depth $0.8 \mathrm{~m}$.
- Ash content: $15.4 \%$, HTL biocrude oil yield: $43 \%$ of ash-free dry weight.

- N and S contents of HTL biocrude oil: $5 \%$ and $0.3 \%$, respectively.

- Biocrude oil production: 1.3-1.7 times higher than lipid content 
Table 4. Effluent quality of HRAP system compared with conventional wastewater treatment ponds in New Zealand (Integrated Tables 1 and 2 in Craggs et al. [18]).

\begin{tabular}{|c|c|c|c|c|c|c|c|c|}
\hline \multirow{2}{*}{$\begin{array}{l}\text { Water Quality } \\
\text { Variables (ppm) }\end{array}$} & \multicolumn{2}{|c|}{$\begin{array}{c}\text { Conventional WTP } \\
\text { System }\end{array}$} & \multicolumn{2}{|c|}{ HRAP System } & \multicolumn{2}{|c|}{$\begin{array}{c}\text { HRAP System with } \\
\mathrm{CO}_{2} \text { Addition }\end{array}$} & \multicolumn{2}{|c|}{$\begin{array}{c}\text { HRAP System with P } \\
\text { Flocculation }\end{array}$} \\
\hline & Median & 95 PCTL & Median & 95 PCTL & Median & 95 PCTL & Median & 95 PCTL \\
\hline BOD & $<40$ & $<110$ & $<15$ & $<50$ & $<15$ & $<40$ & $<10$ & $<30$ \\
\hline TSS & $<80$ & $<150$ & $<15$ & $<60$ & $<15$ & $<40$ & $<10$ & $<30$ \\
\hline $\mathrm{NH}_{4}-\mathrm{N}$ & $<10$ & $<30$ & $<5$ & $<20$ & $<2$ & $<10$ & $<4$ & $<15$ \\
\hline TN & $<10$ & $<50$ & $<10$ & $<40$ & $<5$ & $<15$ & $<5$ & $<15$ \\
\hline DRP & $<10$ & $<15$ & $<5$ & $<10$ & $<2$ & $<5$ & $<1$ & $<5$ \\
\hline $\mathrm{TP}$ & $<10$ & $<15$ & $<7$ & $<15$ & $<7$ & $<10$ & $<2$ & $<10$ \\
\hline $\begin{array}{c}\text { E. coli } \\
\text { (MPN/100 mL) }\end{array}$ & $<40,000$ & $<400,000$ & $<100$ & $<1000$ & $<100$ & $<1000$ & $<100$ & $<1000$ \\
\hline
\end{tabular}

The polyculture of native algal communities has been used for algae biomass production and wastewater treatment in open ponds and bioreactors (Table 3) $[14,16-19,26-$ 28,76-83]. However, there is little information on the compositional dynamics of the native algal community in polyculture. Demura et al. [14] showed that, in most cases, polyculture biomass typically consists of $70-90 \%$ algae; however, the rest consists of bacteria, fungi, amoeba, ciliates, and some invertebrates. Species and taxa numbers decreased as the cultivation time increased, but productivities remained high in raceway ponds. They showed that species selection had occurred, with adapted algal species producing large amounts of biomass. In the period with decreased species and taxa diversity, "selected" native algal species may maintain stable and large biomass productivity. Desmodesmus sp. and Scenedesmus acuminatus were the dominant species. The authors provided several possible explanations for this dominance: (1) the bristles of Desmodesmus sp. cells may reduce predation pressure from small-sized predators; (2) various Scenedesmus species may inhibit the growth of other microalgae in mixed cultivations; (3) Scenedesmus and Desmodesmus show a short reproductive cycle of the coenobium, followed by the rapid formation and release of four-cell dominant coenobia over a wide temperature range, resulting in dominance over a wide temperature range. Complementary to Desmodesmus, the filamentous alga Klebsormidium sp. flourished at a cold temperature. Klebsormidium occasionally occurs in natural algal communities of wastewater ponds [84]. It has high species diversity, even in polar regions [85]. The adjustability of this genus to low temperatures may have contributed to the stable productivity of algal biomass during the winter season [14].

The performance of photosynthetic microalgae biomass production in the outdoor reactor system is mainly a function of solar radiation availability and culture depth of the reactor because light impinging on the reactor surface is attenuated along the culture depth due to an increase in algal cells in the culture [86]. Considering that fixation of nutrients by photosynthetic microalgae is a direct function of average irradiance, the shallower the culture depth, the higher the average irradiance, the higher the fixation rate of nitrogen and phosphorus, and the higher the biomass productivity. Thus, to maximize the photosynthetic microalgal biomass production and nutrient recovery from wastewater, the culture depth must be shallow, below $0.2 \mathrm{~m}$ [23]. This interrelationship applies for photosynthetic algae but not for mixotrophic microalgae.

Several studies have been conducted to optimize algal biomass production in polyculture with respect to depth $[14,19,78]$. When the seasonal algal performance in the polyculture high-rate algal ponds (HRAPs) using wastewater at three depths of $0.2,0.3$, and $0.4 \mathrm{~m}$ was evaluated, a $0.4 \mathrm{~m}$ deep HRAP resulted in $134 \%$ to $200 \%$ higher aerial productivity than a $0.2 \mathrm{~m}$ deep HRAP and was more efficient at $\mathrm{NH}_{4}-\mathrm{N}$ uptake [19]. However, the opposite results have been obtained [78]. The discrepancy may be caused by the differences in time, place, and algal components. Demura et al. [14] demonstrated in the mixotrophic microalgae-dominant polyculture induced by adding sodium acetate that the overall areal productivity increased significantly with increasing depth from $0.1 \mathrm{~m}$ to $0.8 \mathrm{~m}$. Figure 1 
shows that monthly algae biomass productivities in $0.8 \mathrm{~m}$ depth culture remained at a stable value of $24.4-32.8 \mathrm{~g} \cdot \mathrm{m}^{-2} \cdot$ day $^{-1}$ (mean productivity $28.1 \mathrm{~g} \cdot \mathrm{m}^{-2} \cdot$ day $^{-1}$ ) despite the seasonal fluctuation of temperature ranging from $7^{\circ} \mathrm{C}$ in winter to $25^{\circ} \mathrm{C}$ in summer and photon flux density ranging from $307 \mu \mathrm{mol} \cdot \mathrm{m}^{-2} \cdot \mathrm{s}^{-1}$ in December (winter solstice month) to $540 \mu \mathrm{mol} \cdot \mathrm{m}^{-2} \cdot \mathrm{s}^{-1}$ in May (one month before summer solstice).

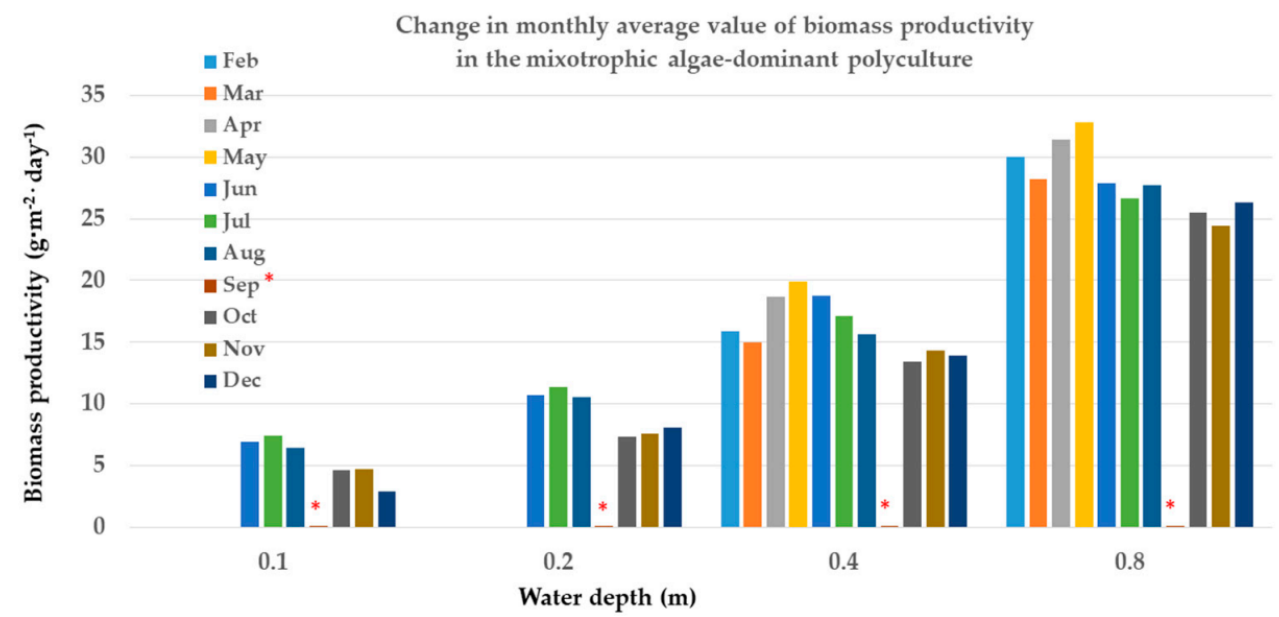

Figure 1. Biomass productivity in culture vessels with different water depths (September-December data added to Demura et al. [14] showing data from February to August. * September data missing due to flood damage.

However, with the biomass and biocrude-oil productivities of $0.8 \mathrm{~m}$ deep culture (Figure 1 and Table 3), the land area required to cover the imported amount $\left(0.13 \times 10^{9} \mathrm{t}\right)$ of crude oil in Japan is 3.7 million ha, which is 2.7 times larger than the total area (1.37 million ha) of the sewage treatment facility. To solve such a critical land issue, mixotrophic algaebased polyculture at a water depth of $1.4 \mathrm{~m}$ using primarily treated sewage has been conducted throughout the year [25]. A much higher biocrude oil productivity of more than 300 tons $\cdot \mathrm{ha}^{-1} \cdot$ year $^{-1}$ was obtained; thus, the land area required to fulfill the imported amount of crude oil is estimated to be less than $32 \%$ of the total area of sewage treatment facilities. Therefore, such a deep water-depth polyculture of mixotrophic algae combined with the wastewater treatment process can meet the current demand of crude oil in Japan.

\subsection{Wastewater Treatment by Algae}

The activated sludge treatment system used mostly in high-income countries has a high organic-matter removal from wastewater. The system efficiently purifies the sewage in a small area, but the operation/management costs and energy consumption are high. On the other hand, the conventional wastewater treatment pond system is cost-effective, requires little maintenance, and generally works well to remove organic solids in wastewater. However, the pond system needs a large area; it is not designed to optimize the recovery of natural resources from wastewater, such as nitrogen, phosphorus, and algae/bacterial biomass for biofuels.

HRAP systems were developed by Oswald and co-workers at the University of California, Berkeley [87]. HRAPs are shallow raceway ponds that circulate wastewater via a low-power paddle wheel. HRAPs are designed to maximize the breakdown of organic waste via algal and bacterial growth and inactivate pathogens through sunlight exposure. Based on a symbiotic relationship between bacteria and microalgae, they provided lowenergy wastewater treatment and recovered nutrients as harvested algal biomass that could be used as a biofuel feedstock. Several systems are operating in northern cities in California State [3,88], Christchurch in New Zealand [17,89], and Spain [90]. Christchurch's HRAP system of polyculture consists of a covered anaerobic pond (CAP), HRAP, algae settling and harvesting pond, mature pond (MP), and rock filter [18]. Depending on 
the climate, the maximum organic loading rate of HRAP is between 100 and $150 \mathrm{~kg}$ $\mathrm{BOD}_{5} \cdot \mathrm{ha}^{-1} \cdot \mathrm{day}^{-1}$. The HRAP depth depends on wastewater clarity (typically $0.2-0.6 \mathrm{~m}$ ). In temperate climates, the hydraulic retention time varies seasonally (3-4 days in summer and 7-9 days in winter). The system was designed to treat wastewater to meet all discharge requirements for $\mathrm{BOD}, \mathrm{TSS}, \mathrm{NH}_{4}-\mathrm{N}, \mathrm{TN}$, and TP. $\mathrm{CO}_{2}$ addition doubled the biomass productivity to $16-20 \mathrm{~g} \cdot \mathrm{m}^{-2} \cdot \mathrm{day}^{-1}$, improving effluent quality. In addition, a low level of chemical flocculants improved the effluent quality the most; for instance, the removal of TP was remarkable [18] (Table 4).

The HRAP polyculture system had high disinfection performance for fecal bacteria/viral indicator organisms and actual human pathogenic viruses from influent to final MP [89]; the removal of Escherichia coli from $10^{6}$ to $10^{2}$ order MPN. $100 \mathrm{~mL}^{-1}$ in winter and summer; Enterococci from $10^{7}$ to $10^{2}$ order MPN.100 mL $\mathrm{mL}^{-1}$ in winter and from $10^{7}$ to $10^{4}$ order in summer, and fRNA from $10^{5}$ to $10^{1}$ order PFU. $100 \mathrm{~mL}^{-1}$ in winter and summer; adenovirus from $10^{5}$ to $10^{4}$ order copies $100 \mathrm{~mL}^{-1}$ in winter and from $10^{6}$ to $10^{1}$ order copies $\cdot 100 \mathrm{~mL}^{-1}$ in summer; enterovirus from $10^{5}$ to $10^{3}$ order copies $100 \mathrm{~mL}^{-1}$ in winter and from $10^{5}$ to $<10^{1}$ order copies $100 \mathrm{~mL}^{-1}$ in summer; rotavirus from $10^{5}$ to $<10^{1}$ order copies $\cdot 100 \mathrm{~mL}^{-1}$ in summer. Only norovirus was not removed in winter and summer.

Thus, HRAP has a high performance in treating wastewater to meet discharge requirements, removing human pathogenic viruses and achieving high productivity of algae-dominant polyculture toward future algae-based biofuel production. However, a large area is required to treat a large amount of wastewater using the HRAP system. For example, most public sewage treatment plants in Japan treat 10,000 to $500,000 \mathrm{~m}^{3}$ of sewage daily. At least 5 ha-250 ha land areas are needed for a HRAP at a $0.2 \mathrm{~m}$ culture depth. Two-thirds of the islands of Japan consist of mountainous areas; the flat land is mostly occupied by cities, industrial zones, and agriculture, and it is extremely expensive to acquire. Thus, integrating wastewater treatment and algae biomass production should be developed using a system with a low land footprint in Japan and other countries with limited usable lands.

In the polyculture of the native algae community with $0.8 \mathrm{~m}$ water depth, BOD, TSS, $\mathrm{TN}$, and TP of culture effluent without adding flocculants were reduced by $82.8 \%, 48.5 \%$, $64.2 \%$, and $32.1 \%$, respectively. The addition of flocculants reduced these nutrients below the levels of the quality standard of discharge water based on the Sewage Act in Japan (Table 5) [26], suggesting that even $0.8 \mathrm{~m}$ deep algal culture efficiently purifies sewage in a small area. Developing a mixotrophic microalgae polyculture plant system with a low area-to-volume ratio would solve the above bottleneck by integrating sewage treatment and algae biomass production, resulting in low land-footprint algae-based fuel production.

Table 5. Nutrient removal in primarily treated sewage polyculture with $0.8 \mathrm{~m}$ culture depth (estimated from the figure of water quality test [26].

\begin{tabular}{ccccc}
\hline $\begin{array}{c}\text { Water Quality } \\
\text { Variables }\end{array}$ & $\begin{array}{c}\text { Quality Standard of } \\
\text { Discharge Water Based on } \\
\text { the Sewage Act in Japan }\end{array}$ & Influent & Effluent & $\begin{array}{c}\text { Effluent after } \\
\text { Flocculant } \\
\text { Treatment }\end{array}$ \\
\hline BOD (ppm) & $<15$ & 252.6 & 43.4 & 7.9 \\
TSS (ppm) & $<40$ & 158.4 & 81.6 & 2.7 \\
TN (ppm) & $<20$ & 38.8 & 13.9 & 7.3 \\
TP (ppm) & $<3$ & 5.6 & 3.8 & 0.2 \\
\hline
\end{tabular}

Recently, numerous studies have been conducted on the performance of microalgaeactivated sludge consortia treating synthetic wastewater under defined laboratory conditions [91-99]. Although there have been many differences in algae components, algaeactivated sludge ratios, and experimental designs and conditions, the reduction rates shown under each optimal condition in these reports can be summarized as follows. The reduction efficiencies of COD, $\mathrm{NH}_{4}-\mathrm{N}$, TN, and TP are $91.2 \pm 5.0 \%, 95.3 \pm 7.6 \%, 66.7 \pm 27.5 \%$, and $75.2 \pm 30.5 \%$, respectively. Despite great TN and TP removal variations due to different ex- 
perimental designs and conditions, there is slight variation in the $\mathrm{COD}$ and $\mathrm{NH}_{4}-\mathrm{N}$ removal rates. These studies on activated sludge and algae consortium are similar to polycultures consisting of $70 \%$ to $90 \%$ algae, bacteria and other microorganisms and invertebrates. From the viewpoint of future applications to actual sewage treatment sites, these studies should be followed by an in situ pilot-scale demonstration experiment. It is worth noting that in situ pilot-scale investigations are being conducted by the Environmental Engineering team at New Mexico State University [100] and by the technology entity led by MicroBio Engineering Inc.-California Polytechnic State University [88]

\section{Harvesting and Dewatering}

The conversion of algal biomass from ponds or bioreactors into liquid biofuel requires processing steps, such as harvesting/dewatering, and various pathways extraction of organic matter (e.g., carbohydrates, proteins, and lipids). Harvesting is the process of separating biomass (suspended solids) from a liquid culture medium. The algae biomass concentration significantly varies from that in diluted algal culture to that in dry algal powder. The combination of small cell size $(2-40 \mu \mathrm{m})$ and low cell density $(0.3$ to 5.0 $\mathrm{g} \cdot \mathrm{L}^{-1}$ equivalent to 0.03 to $0.5 \mathrm{wt} \%$ solid content) creates a significant challenge for the biomass recovery process [101]. However, to remove large volumes of water and process great quantities of algal biomass, a suitable harvesting method requires multiple steps of physical, chemical, or biological methods to perform the desired solid-liquid separation. Table 6 presents an overview of the most common dewatering technology associated with biomass concentration and energy consumption.

Table 6. Overview of most common dewatering technology associated with biomass concentration and energy consumption.

\begin{tabular}{|c|c|c|c|c|}
\hline \multirow{2}{*}{$\begin{array}{l}\text { Dewatering } \\
\text { Technology }\end{array}$} & \multicolumn{2}{|c|}{$\begin{array}{c}\text { Biomass Concentration } \\
\text { ( } \% \text { TSS) }\end{array}$} & \multirow{2}{*}{$\begin{array}{c}\text { Energy } \\
\text { Consumption } \\
\left(\mathrm{KWh} / \mathrm{m}^{3}\right)\end{array}$} & \multirow[t]{2}{*}{ Ref. } \\
\hline & Input & Output & & \\
\hline Micro-strainer & \multirow{5}{*}{$<0.1$} & 1.5 & 0.20 & [102] \\
\hline Gravity sedimentation & & 1.5 & 0.10 & [103] \\
\hline Flocculation & & $2-8$ & $0.15-2.4$ & {$[104,105]$} \\
\hline Filter basket & & 5.0 & 0.20 & [106] \\
\hline Dissolved air flotation & & 6.0 & 20.00 & [107] \\
\hline Vibrating screen & \multirow{5}{*}{$0.1-0.5$} & 6.0 & 0.40 & [102] \\
\hline Filter thickener & & 7.0 & 1.60 & [106] \\
\hline Cylindrical sieve & & 7.5 & 0.30 & [102] \\
\hline Suction filter & & 8.0 & 0.10 & [106] \\
\hline Vacuum drum & & 8.0 & 5.90 & [108] \\
\hline Belt filter & 4.0 & 9.5 & 0.45 & [106] \\
\hline Belt filter press & 0.5 & 18.0 & 0.50 & [102] \\
\hline Centrifugation & 0.1 & 22.0 & 8.00 & [103] \\
\hline \multirow[t]{2}{*}{ Chamber filter } & 5.0 & 27.0 & 0.88 & [106] \\
\hline & & \multicolumn{3}{|c|}{$\left(\mathrm{KWh} / \mathrm{Kg} \mathrm{BM}_{\mathrm{DW}}\right)$} \\
\hline \multirow{2}{*}{ Drum Dryer } & \multirow{2}{*}{20} & $>90.0$ & 8.7 & [109] \\
\hline & & 96.0 & 3.5 & [110] \\
\hline Spray dryer & 2.0 & 95.0 & 35.0 & [108] \\
\hline
\end{tabular}


The selection of the harvesting technique depends on the characteristics of microalgae, e.g., the cell size, density, and value of the target products. It is also crucial to the economic production of microalgae biomass. For large-scale algae biomass production, microalgae harvesting is mainly a two-stage process (Figure 2) and accounts for $20-30 \%$ of the total production costs, excluding drying costs [106]. Removing free bulk water from suspended solids at low solid concentrations requires less energy than the relatively small amount of the remaining water (sometimes refers to moisture content) after mechanical dewatering force (Figure 2). Thermal energy is required to remove moisture from the concentrated wet algae paste, and when derived from fossil fuels, the impact on GHG emissions is notably high.

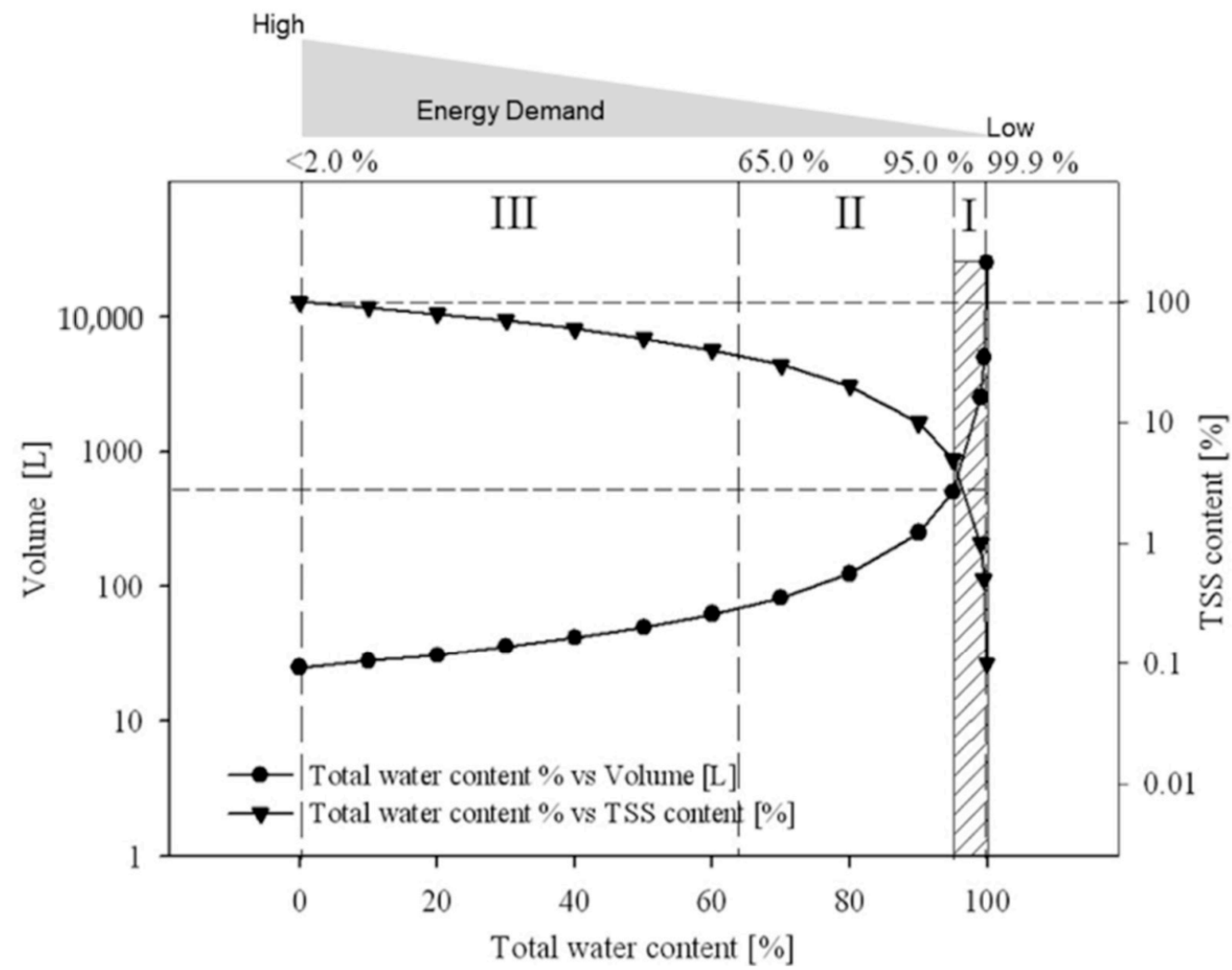

Figure 2. Relationship between volume and total suspended solids from harvesting of the determined volume algal culture, followed by thickening (I), dewatering (II), and drying (III), which was prepared based on the literature shown in Table 6.

The reduction of energy consumption to combine dewatering by flocculation and mechanical force (two-stage process) has been recognized as the most energy-efficient methodology [104]. It has been demonstrated that large-scale and effective methods for drying biomass incur prohibitive energy costs [111]. In contrast, with processing methods for wet biomass (up to about $20 \%$ solids), transport becomes prohibitively expensive, and on-site processing is required. The "Carnegie Project", which was pioneered from the great achievements during the first conceptualization of algae mass culture, was the supplementation, or even replacement, of algae biomass to animal protein for direct consumption by humans [112]. Based on this project, the classic book edited by Burlew in 1953 [113] on microalgae mass cultivation was written, summarizing many early studies on microalgae. Since then, considerable efforts have been made to improve the efficiency of the economics of large-scale microalgae harvesting and processing. These achievements have been reported and discussed extensively in the literature [102,105,108,114,115]. In this section, we will focus on the processing methods eligible for subsequent HTL and reasonable algal 
biofuel life cycle assessments. The most common thickening and dewatering methods include sedimentation, filtration, and centrifugation.

\subsection{Sedimentation}

Sedimentation is the simplest step in liquid-solid separation by gravity, with low power consumption and a simple design but low solid concentration output and a large area footprint requirement. A large area is required for the lamellar settler, where the distance for settling particles is shortening. This method is suggested for separating algae cultures, and it is used in wastewater treatment [108]. However, sedimentation, as described by Stokes' law, and sedimentation rates are affected by the cell size, cell density, cell motility, and water turbulence. For example, the average solid content of $1.6 \%$ with Coelastrum proboscideum was obtained, which is sufficient for pre-concentration [102]. Unlike filamentous algae, unicellular microalgae are small in size and do not settle naturally under normal growth conditions.

As mentioned above, flocculation is an essential step for microalgae-based wastewater treatment to meet discharge requirements $[18,26]$. Flocculation has been used as a step-in addition to or in combination with flocculation-flotation, to increase the particle size of microalgal cells and improve the efficiency of sedimentation, centrifugation, and filtration. The flocculation method is used to separate the biomass from the bulk suspension. The concentration factors for this method are typically 100-800 times to achieve $2-8 \%$ total solid matter [104]. Flocculation describes the formation of cells into aggregates to increase the effective particle size using various methods.

- Flocculation by inorganic chemicals

- Flocculation by organic chemicals

- Bio-flocculation

- Auto-flocculation

- Ultrasound and Electro-flocculation/flotation

In this subsection, we consider the most proven techniques, such as flocculation, using inorganic and organic chemicals. Flocculation sometimes refers to the term coagulation, which describes the aggregation resulting from $\mathrm{pH}$ adjustment or electrolyte addition; however, aggregation because of polymer addition is termed flocculation [116]. As mentioned above, during algae biomass cultivation, the negative charge of microalgae cells prevents cell aggregation in a suspension. However, the surface charge can be neutralized or reduced by adding flocculants, such as multivalent cations and cationic polymers. The flocculants should be inexpensive, non-toxic, and effective at low concentrations; they should also be selected with no regard for downstream processes [106]. Metal ions, such as $\mathrm{Al}^{+3}, \mathrm{Fe}^{+3}$, and $\mathrm{Mg}^{+2}$, are used mainly as inorganic chemicals that form hydrates at suitable $\mathrm{pH}$. Lime $\left(\mathrm{Ca}(\mathrm{OH})_{2}\right)$ is commonly used in water and wastewater treatment for $\mathrm{pH}$ adjustment. The most effective metal salt was aluminum sulfate; however, it is expensive in large amounts [117].

Polymeric organic flocculants are an alternative to inorganic chemicals, such as metal salts (polyelectrolytes). Polyelectrolytes have the advantage of producing a threedimensional matrix for more stable flocks because of their reduced surface charge and physically bridging algal cells and polymer chains. The efficiency is increased by highmolecular-weight polymers and a low $\mathrm{pH}[118,119]$. The most well-known polyelectrolytes with a long history for commercial applications are chitosan, Zetag63, Zetag92, and N100 [120]. Organic flocculants have a lower toxicity risk, which is a significant advantage. However, Udom et al. [121] found that ferric chloride and alum have significantly lower GHG emissions, with $10 \mathrm{~kg} \mathrm{CO}_{2}$-e.ton ${ }^{-1}$ dry algae and $62 \mathrm{~kg} \mathrm{CO}_{2}$-e.ton ${ }^{-1}$ dry algae, respectively, than $110 \mathrm{~kg} \mathrm{CO}_{2}$-e. ton $^{-1}$ dry algae for polymers.

\subsection{Filtration}

Filtration is one of the most promising processes for solid-solid or liquid-solid separation. The filtration principle introduces particles into a filter mesh with a specific pore 
size [108]. Compared with the operating principle of a centrifuge, which relies mainly on centrifugal force and the specific gravity of the solid, filtration is based on the separation of solid from liquid through the pore size of the filter mesh, which is dictated by the particle size of the aggregated algae cells. Filtration systems have been developed with driving forces such as gravity, centrifugal, pressure, or vacuum [102]. A solid concentration of $27 \mathrm{wt} \%$ has been achieved using a chamber filter press with an estimated energy consumption of $0.88 \mathrm{kWh} \cdot \mathrm{m}^{-3}$ and a micro strainer with the lowest energy consumption of $0.2 \mathrm{kWh} \cdot \mathrm{m}^{-3}$ and a solid concentration of $1.5 \%$. A pre-coated filter with potato starch for a vacuum drum filter achieved a solid concentration of 37\% [102]. Recently, a research group in the Netherlands conducted a techno-economical evaluation of algae harvesting and dehydration considering a 100 ha scale [104]. Consequently, harvest and dehydration with the lowest cost and high energy efficiency combined coagulation precipitation with chitosan-pressure filtration. The cost and energy consumption were calculated to be EUR $0.36 \cdot \mathrm{kg}^{-1}$ dry algae and $0.03 \mathrm{kWh} \cdot \mathrm{kg}^{-1}$ dry algae, respectively. Similar results for GHG emissions have been reported by Udom et al. [121] with $5.0 \mathrm{~kg} \mathrm{CO}_{2}$-e-ton ${ }^{-1}$ dry algae for belt press technology compared to $50 \mathrm{~kg} \mathrm{CO}_{2}$-e $\cdot \mathrm{ton}^{-1}$ dry algae for centrifugation. The combination of energy-efficient filtration technologies and high-efficiency sedimentation using flocculation will significantly reduce the carbon footprint for algae biofuel production.

\subsection{Centrifugation}

Centrifugation is a sedimentation process with enhanced gravitational force to increase the sedimentation rate within a chamber, allowing easier solid movement through a liquid [122]. The centrifugal separation process has been investigated for almost all types of microalgae, with high value metabolites and algae concentrate for hatcheries and nurseries in aquaculture [101,108]. Centrifugation is a rapid process whose biomass recovery depends on the slurry residence time in the centrifuge and settling distance. The different types of centrifuges cover a wide range of particle sizes (from $10^{-3}$ to $10^{4} \mu \mathrm{m}$ ) [122]; however, not all types of centrifuges are suitable for continuous operation. A few centrifuges, e.g., nozzle centrifuge, screw centrifuge, and self-cleaning plate separator, are used at industrial scales; they can achieve a solid content of about $15 \mathrm{wt} \%$. High energy demand and a high level of maintenance have been recognized as a disadvantage for centrifuge application. In contrast, decanter-type centrifuges are the most promising because they can operate continuously and have high capacity and lower maintenance requirements [123].

\section{Conversion of Algae Biomass into Bio-Crude Oil through HTL}

The following is a summary of the advantages of hydrothermal liquefaction technology:

- Robust and reliable: can be applied to wide range of carbon rich feedstocks at similar processing conditions.

- Conceptually simple (feed preparation, pump, heated pipe, separation of biocrude).

- Wet feedstocks with 70-90\% moisture such as microalgae biomass, agriculture residues, sludge, manure, and pulp mill residue can be processed.

- The HTL biocrude oil is thermally stable and can be readily upgraded.

- High carbon efficiency of product: greater than 50\% carbon conversion from the feedstock to hydrocarbon fuel product.

- Favorably comparable in economics with other biomass conversion technologies such as pyrolysis.

A large number of laboratory and pilot investigations on HTL have been reported trialing different feedstocks, reactor configurations, and catalysts to improve the product quality and yields [124-129]. Some HTL technologies have now matured and moved into commercial production by various companies in different countries such as Silva Green Fuel (Norway), Altaca Energy (Turkey), and Licella Pty Ltd. (Australia). The biocrude oils produced are used as fuel for heating or for co-processing in petroleum refineries. In 
most cases, co-products such as electricity, hydrocarbon gases, and green chemicals are also produced that improve the technology economics.

In this section, an availability of HTL methods for algal polycultures, including a deep water-depth polyculture of mixotrophic algae, is evaluated from the viewpoint of biocrude-oil yield and composition.

Developments on catalytic hydroprocessing technologies of biomass-derived liquefaction conversion products have usually been referred to as biocrude or bio-oil for almost four decades [130]. Over this period, the development of HTL has been broadened in subcritical conditions with and without catalysts, supercritical conditions, and a two-stage conversion process for the simultaneous extraction of value-added co-products such as carbohydrates and proteins [4]. The two-stage conversion process was mainly developed for macroalgae as a potential feedstock for biocrude-oil production. However, HTL is a promising technology widely used under subcritical reaction conditions of $250^{\circ} \mathrm{C}$ to $374^{\circ} \mathrm{C}$ and 5 to $25 \mathrm{MPa}$ pressure at different reaction times between 5 and $60 \mathrm{~min}[131,132]$ to produce biocrude and bio-based chemicals $[133,134]$.

HTL is a water-based process; it is therefore suitable for the carbon-rich matter at high moisture contents of about $80 \mathrm{wt} \%$. The process replicates the formation of conventional hydrocarbons found in fossil crude oil by converting macromolecules to smaller molecules and reforming them to hydrocarbon products through a series of hydrolysis, depolymerization, and re-polymerization reactions [124,135]. Microalgae can be readily converted into transportation liquid fuels and chemicals using advanced thermal conversion technologies such as HTL [130]. The main products of the HTL process are categorized as follows [136]:

1. Biocrude oil-the primary product: it has properties similar to conventional petroleum. 2. Solid residues: it is used as a soil amendment for agricultural applications.

3. Aqueous phase: it contains essential nutrients including phosphorus that can be used to cultivate algae or other biomass resources. Alternatively, the remaining carbon content in the aqueous phase can produce synthetic natural gas by gasification or methane by anaerobic digestion.

4. Gas phase, which contains more than $90 \%$ of $\mathrm{CO}_{2}$ and trace amounts of hydrocarbon gases $\left(\mathrm{CH}_{4}, \mathrm{C}_{2} \mathrm{H}_{4}\right.$, and $\left.\mathrm{C}_{2} \mathrm{H}_{6}\right)$.

It has been reported that the biocrude-oil yields and compositions obtained through HTL for numerous monoalgal-species are $18 \%$ to $87.2 \%$ in yield, $5.9 \%$ to $36.5 \%$ in ash content, $0.9 \%$ to $9.8 \%$ in N content, and $0.18 \%$ to $1.4 \%$ in sulfur content (except for Porphyridium, growing in high sulfur conditions at hot springs) $[4,127]$. Table 3 shows that polycultures of algae using sewage result in an HTL biocrude yield and quality $[16,27,70,71,74,78,82,83]$ that matches the average monoculture. However, Goswami et al. [83] reported that the biocrude-oil yield obtained from algae-bacteria consortium is 39\% lower than that of mixed microalgae culture [76]. They suggested that such an inferior yield might be due to the un-optimized process parameters and quality of the biomass stocks [83].

Importantly, HTL avoids the intensive energy required for drying feedstocks, as in the other thermochemical reaction technologies, such as gasification and pyrolysis [137,138]. It is worth noting that fossil crude oil is pumped from the ground at 10\% oil and $90 \%$ water containing impurities, such as gases $\left(\mathrm{CO}_{2}, \mathrm{H}_{2} \mathrm{~S}\right.$, and natural gas), minerals, and sand, requiring several pre-treatment steps before being transferred to the refinery. After removing gases and minerals, the water is removed through distillation, leaving only $2 \%$ of water in the fossil crude. Due to the limitation at the laboratory scale, few of these process steps have been applied for biocrude-oil production through HTL.

The energy efficiency of HTL technology is determined primarily by the thermodynamic properties of water, along with efficient heat recovery in a well-engineered reactor system and further process integration. The energy demand for the HTL process is dominated by the energy demand for heating the reactor with $6.51 \mathrm{MJ} \cdot \mathrm{kg}^{-1}$ dry algae; this has been predicted to be slightly decreased at the industrial scale. The reasons for the slight decrease are the implementation of heat recovery and the combustion of process gases with the increased volume per unit and reduced heat transfer due to material thickness. The 
biocrude oils and gases produced through HTL were experimentally determined to have a high heating value of 34 and approximately $1.1 \mathrm{MJ} \cdot \mathrm{kg}^{-1}$, respectively. However, one of the major challenges of the HTL process is the presence of undesirable heteroatoms in biocrude oil [124,139], such as nitrogen, oxygen, and sulfur, which are derived from proteins, carbohydrates, and lipids in the biomass feedstock. The presence of these hetero-atoms requires further upgrading/refining processes, such as hydrotreatment, followed by distillation, which significantly increases the GHG emission reported by Fortier et al. [140].

Furthermore, it is worth noting that, for more than half a century, oil refineries have been producing a wide range of chemicals from any quality of crude oil, including transportation fuels. These refineries can also remove oxygen, nitrogen, and sulfur from low quality crude oil using hydrogenation, hydro-denitrogenation, and hydro-sulfurization devices. The employed technology enables the refinement of various transportation fuels from crude oil of any quality. However, only crude oil cannot be created using them. It is required to reduce the biocrude-oil production cost so that the oil refineries can acquire it at economical feasible price.

\section{Life-Cycle Assessment (LCA) of Microalgae-Based Biofuel Production}

Currently, there are various pathways for biofuel production from biomass feedstock available. Three generations of biofuels such as bioethanol, biodiesel, and biocrude oil through HTL have been considered in this study. For adequate comparison of various biofuels, the well-to-wheel (WTW) perimeter was applied. WTW includes crop cultivation, harvesting, conditioning, transformation of the crop into biofuel, transportation, and its final use in a vehicle engine. However, the two other perimeters such as well-to-gate (WTG, including crop cultivation, harvesting, conditioning and transformation of the crop into biofuel) and well-to-tank (WTT, also known as well-to-pump, including crop cultivation, harvesting, conditioning, transformation of the crop into biofuel, and transportation to a gas station) have been widely used in the literature [141]. Frank et al. [142] presented a lipid extraction process model of hypothetical wet hexane extraction combined with anaerobic digestion for methane co-production and nutrient recovery. The GHG footprint outcome was 55,400 $\mathrm{g} \mathrm{CO}_{2}$-e $\cdot \mathrm{mmBtu}^{-1}$ (about $52.5 \mathrm{~g} \mathrm{CO}_{2}$-e $\cdot \mathrm{MJ}^{-1}$ ) renewable diesel output. These numbers were later updated [143] to 21,500 $\mathrm{g} \mathrm{CO}_{2}$-e-mmBtu (about $20.4 \mathrm{~g} \mathrm{CO}_{2}-\mathrm{e} \cdot \mathrm{MJ}^{-1}$ ); however, an HTL pathway was also added to greenhouse gases, regulated emissions, and energy use in technologies (GREET) model at 31,000 $\mathrm{g}$ $\mathrm{CO}_{2}$-e $\cdot \mathrm{mmBtu}^{-1}$ (about $29.4 \mathrm{~g} \mathrm{CO}_{2}-\mathrm{e} \cdot \mathrm{MJ}^{-1}$ ). It is worth noting that these values represent hypothetical projections potentially achievable in optimized systems but have not been demonstrated to date. This is important as it indicates good potential for process improvements in the future. However, the modeled aspects used from GREET for resource acquisition, fuel conversion, and pump-to-wheel scenarios are based on mature technology and processes with values at a high level of confidence.

When comparing the major process steps between biodiesel production and biocrude oil production from microalgae (Table 7), there are differences in the biomass production process and downstream process. Biodiesel production from microalgae relies on monoculture cultivation and high lipid productivities. These conditions require the usage of fertilizer and shallow ponds at large area footprints. Both requirements have led to higher $\mathrm{CO}_{2}$ emission vales compared with the proposed deep-water polyculture system for wastewater treatment. Furthermore, the drying process of the biomass for the biodiesel production results in higher $\mathrm{CO}_{2}$ emissions compared with the downstream process required for the HTL conversion. Table 7 summaries the main process steps for the comparison between biodiesel production and biocrude oil production from microalgae, and the values clearly indicate the benefit of the application of HTL for biocrude oil production, producing lower $\mathrm{CO}_{2}$ emissions due to the unnecessity of the drying process and fertilizer. 
Table 7. Comparison of energy balance and $\mathrm{CO}_{2}$ emission between conventional biodiesel production and biocrude oil production, which was prepared from the literature shown in Table 6 and [142,144-146].

\begin{tabular}{|c|c|c|c|c|c|}
\hline Biofuel Feedstock & $\begin{array}{c}\text { Unit } \\
\mathrm{MJ} \cdot \mathrm{kg}^{-1} \mathrm{BM}\end{array}$ & $\begin{array}{l}\text { Production } \\
\text { Process }\end{array}$ & $\begin{array}{l}\text { Energy Input } \\
\mathrm{MJ} \cdot \mathrm{kg}^{-1} \mathrm{BM}\end{array}$ & $\begin{array}{l}\text { Accumulated } \\
\text { Energy Input } \\
\mathrm{MJ} \cdot \mathrm{kg}^{-1} \mathrm{BM}\end{array}$ & $\begin{array}{c}\text { Accumulated } \mathrm{CO}_{2} \\
\text { Emission * } \\
\mathrm{kg}-\mathrm{CO}_{2} \cdot \mathrm{kg}^{-1} \mathrm{BM}\end{array}$ \\
\hline \multirow{4}{*}{ Dry Algae Biomass (BM) } & \multirow{4}{*}{$\begin{array}{c}20 \\
\text { (polyculture } \\
\text { using } \\
\text { wastewater) } \\
24 \\
\text { (monoculture of } \\
\text { high lipid BM) }\end{array}$} & $\begin{array}{l}\text { 1. Cultivation } \\
\text { (pumping, mixing) }\end{array}$ & 2.50 & 2.50 & 0.04875 \\
\hline & & $\begin{array}{l}\text { 2. Cultivation } \\
\text { (Fertilizer use) }\end{array}$ & 5.43 & 7.93 & 0.15464 \\
\hline & & $\begin{array}{l}\text { 3. Harvest- } \\
\text { ing/Dewatering } \\
(\sim 80 \mathrm{wt} \% \text { moisture }\end{array}$ & 1.99 & 9.92 & 0.19344 \\
\hline & & $\begin{array}{l}\text { 4. Drying (from } \\
\sim 80 \mathrm{wt} \% \text { moisture } \\
\text { to }<10 \% \text { moisture) }\end{array}$ & 9.00 & 18.92 & 0.36894 \\
\hline $\begin{array}{l}\text { Net Energy in polyculture } \\
\text { for HTL }\left(\mathrm{MJ} \cdot \mathrm{kg}^{-1} \mathrm{BM}\right) \text { : } \\
\text { process } 1,3)\end{array}$ & \multicolumn{5}{|c|}{15.51} \\
\hline $\begin{array}{c}\text { Net energy in } \\
\text { monoculture of high lipid } \\
\text { BM (MJ.kg }{ }^{-1} \text { dry BM): } \\
\text { process } 1-4\end{array}$ & \multicolumn{5}{|c|}{5.08} \\
\hline \multirow{2}{*}{$\begin{array}{c}\text { Biodiesel (30wt } \% \text { of dry } \\
\text { BM) }\end{array}$} & \multirow[b]{2}{*}{12} & $\begin{array}{l}\mathrm{BM} \text { at }<10 \mathrm{wt} \% \\
\text { moisture }\end{array}$ & & 18.92 & 0.36894 \\
\hline & & $\begin{array}{l}\text { Dry BM extraction } \\
\text { (40 } \mathrm{wt} \% \text { lipids) }\end{array}$ & 0.93 & 19.85 & 0.38708 \\
\hline Glycerol (96 g. $\left.\mathrm{kg}^{-1} \mathrm{BM}\right)$ & 1.65 & $\begin{array}{l}\text { Transesterification } \\
\text { (Methanolysis) }\end{array}$ & 0.87 & 20.72 & 0.40404 \\
\hline Remaining BM (60 wt\%) & 8.15 & & & & \\
\hline Total output at $1 \mathrm{~kg} \mathrm{BM}$ & 21.8 & & & & \\
\hline Net Energy $\left(\mathrm{MJ} \cdot \mathrm{kg}^{-1} \mathrm{BM}\right)$ & & & 1.08 & & \\
\hline \multirow{5}{*}{$\begin{array}{c}\text { Biocrude oil (HTL) } \\
\text { (50 wt } \% \text { conversion rate) }\end{array}$} & \multirow{5}{*}{17.5} & $\begin{array}{l}\mathrm{BM} \text { at } \sim 80 \mathrm{wt} \% \\
\text { moisture }\end{array}$ & & 4.49 & 0.08756 \\
\hline & & $\begin{array}{l}\text { HTL conversion } \\
\left(\mathrm{MJ} \cdot \mathrm{kg}^{-1} \text { biocrude }\right. \\
\text { oil) }\end{array}$ & 3,25 & 7.74 & 0.15093 \\
\hline & & $\begin{array}{l}\text { Solid/liquid } \\
\text { separation } \\
\text { (Tricanter) }\end{array}$ & 0.15 & 7.89 & 0.15386 \\
\hline & & $\begin{array}{l}\text { Dewatering by } \\
\text { sedimentation }\end{array}$ & 0.7 & 8.59 & 0.16751 \\
\hline & & $\begin{array}{l}\text { Thermal water } \\
\text { removal at } \\
\sim 50 \mathrm{wt} \% \text { moisture }\end{array}$ & 1.85 & 10.44 & 0.203580 \\
\hline
\end{tabular}

\begin{tabular}{cc}
\hline $\begin{array}{c}\text { Remaining solids } \\
(\sim 35 \mathrm{wt} \%) \text { for biogas }\end{array}$ & 10.6 \\
\hline $\begin{array}{c}\text { Gas phase }(10-15 \mathrm{wt} \%) \\
\begin{array}{c}\text { Total HTL Output at } 1 \mathrm{~kg} \\
\text { Biomass }\end{array}\end{array}$ & $0.11-0.165$ \\
\hline Net Energy (MJ $\left.\cdot \mathrm{kg}^{-1} \mathrm{BM}\right)$ & 28.21 \\
\hline
\end{tabular}

${ }^{*} \mathrm{CO}_{2}$ emission was estimated based on the unit calorific value of heavy oil in accordance with the guideline of the Ministry of Environment, Japan [147]. 
Figure 3 summarizes the most dominant assessments for biofuel production from microalgae, illustrating the range of life cycle assessment (LCA) outcomes for GHG emission footprints prepared by various research groups $[140,142,143,146,148-150]$. This figure demonstrates that the conventional dry microalgae extraction models have excessively high energy consumption; thus, the drying is not part of the dewatering process. More modern systems are wet extraction, HTL, or secretion based, and whether focused on renewable diesel or jet fuel, they have favorable GHG emissions relative to conventional low-sulfur diesel (dotted line) at about $96 \mathrm{~g} \mathrm{CO}_{2}$-e. $\mathrm{MJ}^{-1}$ fuel and about $88 \mathrm{~g} \mathrm{CO}_{2}$-eq. $\mathrm{MJ}^{-1}$ (dashed line) for conventional jet fuel. However, the GHG emission value for refined jet fuel obtained from HTL biocrude oil increased to twice that of HTL biocrude oil due to removing undesirable heteroatoms.

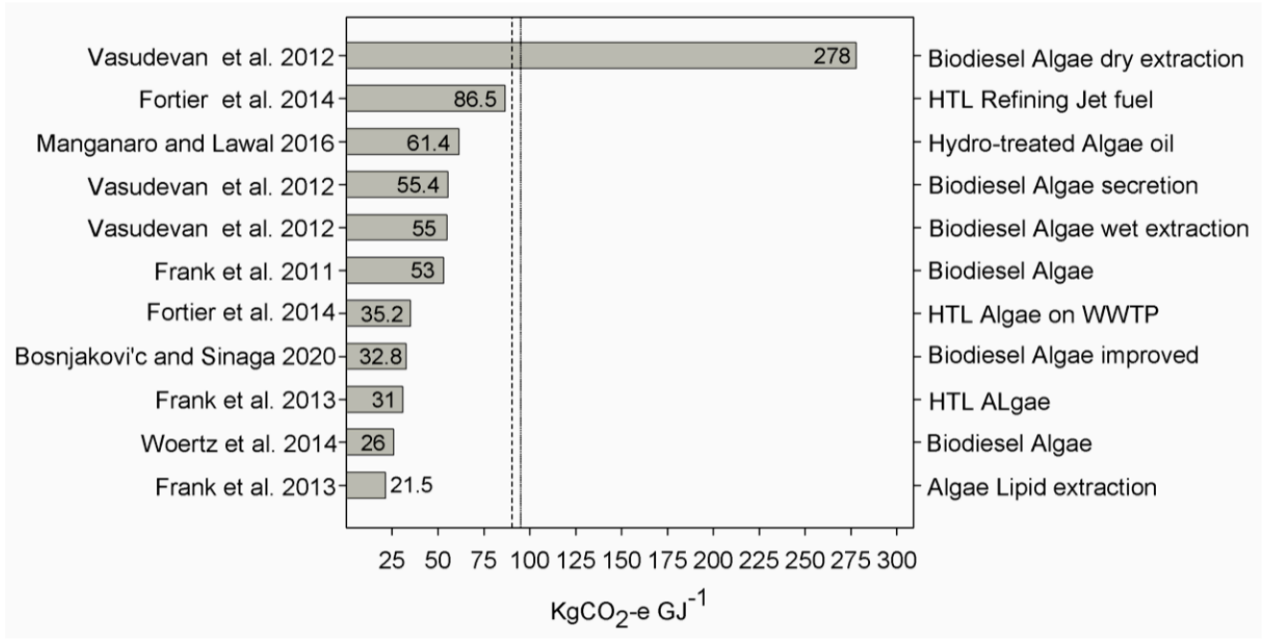

Figure 3. GHG emission footprint of various biofuel options from microalgae fuel models collected from scientific literature [140,142,143,146,148-150].

Given that these values are based on hypothetical models instead of data from industrial production plants, there is a possibility that some values are reported with assumptions about the potential for promising results derived from theoretically optimized systems. However, except for the conventional dry extraction method, most renewable algae fuel production systems showed favorable GHG emissions that were lower than those of conventional diesel and jet fuel (also for ultra-low sulfur diesel). Large microalgae production systems with a massive area footprint should be located on land of low agricultural value (land of low carbon capture capacity), benefiting their potential for biofuel production. The reason is that the effects of land-use change on GHG emissions would be substantial. When land-use change is considered, there is a significant effect on the LCA outcomes of corn ethanol production in the United States of America, according to Tyner et al. [151]. For instance, the GHG footprint for renewable diesel from hydro-treated palm oil (about $30 \mathrm{~g} \mathrm{CO}_{2}-\mathrm{e} \cdot \mathrm{MJ}^{-1}$ ) is almost as low as the best algae case without considering the land change. However, when the land-use change to areas such as peatland rainforest clearings in southeast Asia is considered, the value is dramatically higher (about $705 \mathrm{~g} \mathrm{CO}_{2}-\mathrm{e} \cdot \mathrm{MJ}^{-1}$ ), almost an order of magnitude greater than conventional diesel from fossil sources [148].

The total net energy-gain value for biocrude oil and its co-products is higher than that for biodiesel and its co-products because the energy loss through the biodiesel production is higher compared to the biocrude oil production (Table 7). In addition, the reported high lipid content of microalgae for the potential production of biodiesel production represents the amount of total lipids but not the amount of FAME (C16 and C18) suitable for the transesterification process. Further loss of extracted lipids has been recognized for various cell lyses methods and large-scale extraction applications. These losses on extracted lipids 
will greatly impact the energy-gain value for the biodiesel pathway produced from $1 \mathrm{Kg}$ microalgae biomass.

Figure 4 shows the comparison between EROIs of fossil fuels, first and second generation of biofuel pathway from biomass feedstocks, and HTL biocrude oil from algae. It was clearly demonstrated that EROI of algae HTL biocrude oil is much higher than fossil fuels and comparable to the other biodiesel and bioethanol plants.

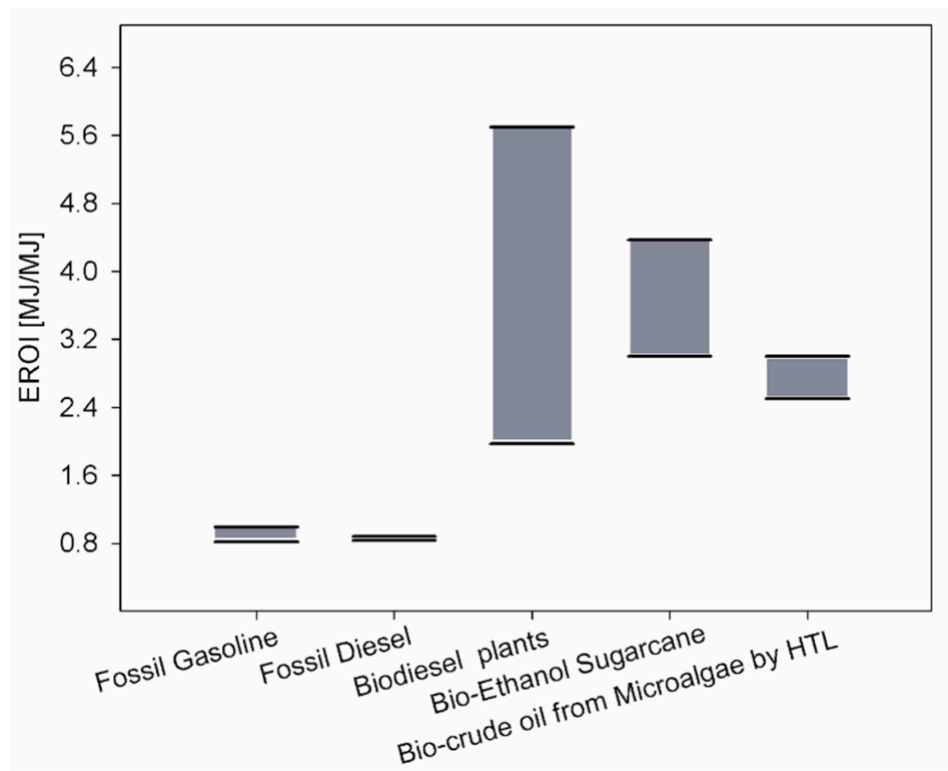

Figure 4. Energy in return of investment values for various pathways of biofuels from terrestrial plants and microalgae [152-154].

Collectively, it is suggested that algae HTL biocrude oil has higher sustainability relative to the conventional liquid fuels and other biofuels, such as bioethanol and biodiesel, for combining GHG and EROI (Figures 3 and 4, Table 7). Thus, in addition to the advantages of HTL of biomass to biofuel as mentioned in Sections 1 and 5, HTL is advantageous also from the sustainability viewpoint.

Table 3 shows that polyculture outperforms the best monoculture by performing multiple functions simultaneously. A WTW-LCA that analyzed the impact of algal biodiversity on biofuel production showed that certain polycultures improved GHG and EROI by $16 \%$ and $20 \%$, respectively, compared to the best monoculture [75]. It has also been suggested that in a $0.8 \mathrm{~m}$ depth polyculture of microalgae, based on $86 \%$ heat recovery in the HTL process previously reported, WTG-LCA of combining algae biomass/biocrude-oil production and wastewater treatment reduced the $\mathrm{CO}_{2}$ emissions of the conventional wastewater treatment system by $33 \%$ [8]. Thus, the benefits for reduced $\mathrm{CO}_{2}$ emission and increased net energy-gain are clearly demonstrated for the proposed biocrude oil production by HTL employing the polyculture system for wastewater treatment.

For the past few decades, especially since 2007, microalgae have been attracting significant attention as a promising source of sustainable biofuels. It tackled major challenges in optimizing upstream and downstream processes for algae fuel production and its practical application. In the harmonized model of the National Renewable Energy Laboratory (NERL), given annual productions of microalgae of 86.8 to 105.4 tons $\cdot \mathrm{ha}^{-1}$ (freshwater algae: FA) and 87.8 to 100.1 tons.ha ${ }^{-1}$ (saltwater algae: SA) in the cultivation area of 5000 acres $(=2025 \mathrm{ha})$ and $50 \%$ of biocrude oil conversion rate through HTL, the minimum fuel sales prices (MFSP) were calculated to be 3.48 to $3.68 \$ \cdot$ GGE $^{-1}$ (gallon gasoline equivalent) and 4.31 to $4.53 \$ \cdot G G E^{-1}$, respectively. In addition, tax incentives have been expanded to include carbon credits for $\mathrm{CO}_{2}$ of $\$ 35$ per ton in the US. Applying this credit to some $\mathrm{CO}_{2}$ incorporated into algal biomass, the MFSP would further reduce to $0.24 \$ \cdot \mathrm{GGE}^{-1}$ for 
FA and $0.23 \$ \cdot G^{-1} E^{-1}$ for SA [60], much cheaper than that of fossil biocrude oil. This model suggests that algae fuel production is economically feasible combined with carbon credits that promote the realization of a low-carbon society. Ishizaki et al. [8] suggested that a 0.8- $\mathrm{m}$ depth polyculture-based wastewater treatment had the same cost-effectiveness as the conventional wastewater treatment, even though the resulting biocrude oil was sold at the same price as fossil crude oil. Thus, further reduction of MFST can be expected by introducing a combination of algae and sewage treatment to the NERL model. However, it has been suggested that algae fuel production alone is not economically feasible and must be combined with other useful by-products. Such a bio-refinery model seems attractive if the significant differences in the size of each market and production standards for feedstock produced for each product can be adjusted well.

It is widely acknowledged that LCA and techno-economic models of complex systems contain many uncertain aspects, as evidenced by the wide range of values observed in the literature when different assumptions are used. There are various scenarios for the economic feasibility of algal fuel and products. Nevertheless, not all of them have been demonstrated, which provide plausible paths to achieve future targets for cost and sustainability metrics. The model outputs still indicate a promising potential for algal biofuels to significantly contribute to the world fuel market. It is essential to accumulate and use real field data to properly validate these models in the future.

\section{Conclusions}

It is commonly recognized that integrating wastewater treatment and microalgae biomass production has multiple benefits, including the circular use of freshwater, reducing the biofuel production cost, and mitigating the impact of contaminated water on the living environment and ecosystems. To realize such benefits, it is necessary to consider how to increase the microalgae production and wastewater treatment capacities. This review highlighted the following:

1. Mixotrophic algae play a significant role in reducing COD/BOD in wastewater such as heterotrophic microbes.

2. Mixotrophic algae have a high potential for solving the bottlenecks of $\mathrm{CO}_{2}$ supply because they can utilize atmospheric $\mathrm{CO}_{2}$ and organic carbon as a carbon source.

3. Mixotrophic algae enable deep water culture, which significantly increases the capacities of aerial productivity of biomass/biocrude oil and wastewater treatment and reduces their land footprints.

4. Polyculture outperforms the best monoculture by performing multiple functions simultaneously, such as producing resilient communities, enabling efficient nutrient uptake, resisting population crashes and undesirable invasive species, and showing fewer tendencies to trade-off between desirable functions.

5. Energy-efficient filtration technologies combined with high-efficiency sedimentation through flocculation will significantly reduce the carbon footprint for algae biofuel production.

6. Algal polycultures using sewage have HTL biocrude oil with a yield and quality that match the average monoculture-derived biocrude oil; it is available for existing oil refineries.

7. HTL has bioavailability of the recycled nitrogen and phosphorus from the aqueous phase.

8. HTL biocrude oil is more sustainable than conventional liquid fuels and other biofuels for combining GHG and EROI.

9. Polyculture has the potential to improve the GHG and EROI significantly, compared with the best monoculture.

Thus, integrating mixotrophic algae polyculture and wastewater treatment processes simultaneously increase microalgae biomass production and wastewater treatment capacities with a low land footprint and high robustness to perturbations. The upgraded upstream process will bring about high efficiency and low carbon footprint in the down- 
stream process. In particular, deep water-depth polyculture of mixotrophic microalgae using sewage has a high potential to produce sustainable biocrude oil within the land area of existing sewage treatment plants to fulfil of the Japanese crude oil demand. Figure 5 shows the diagram of the entire process.

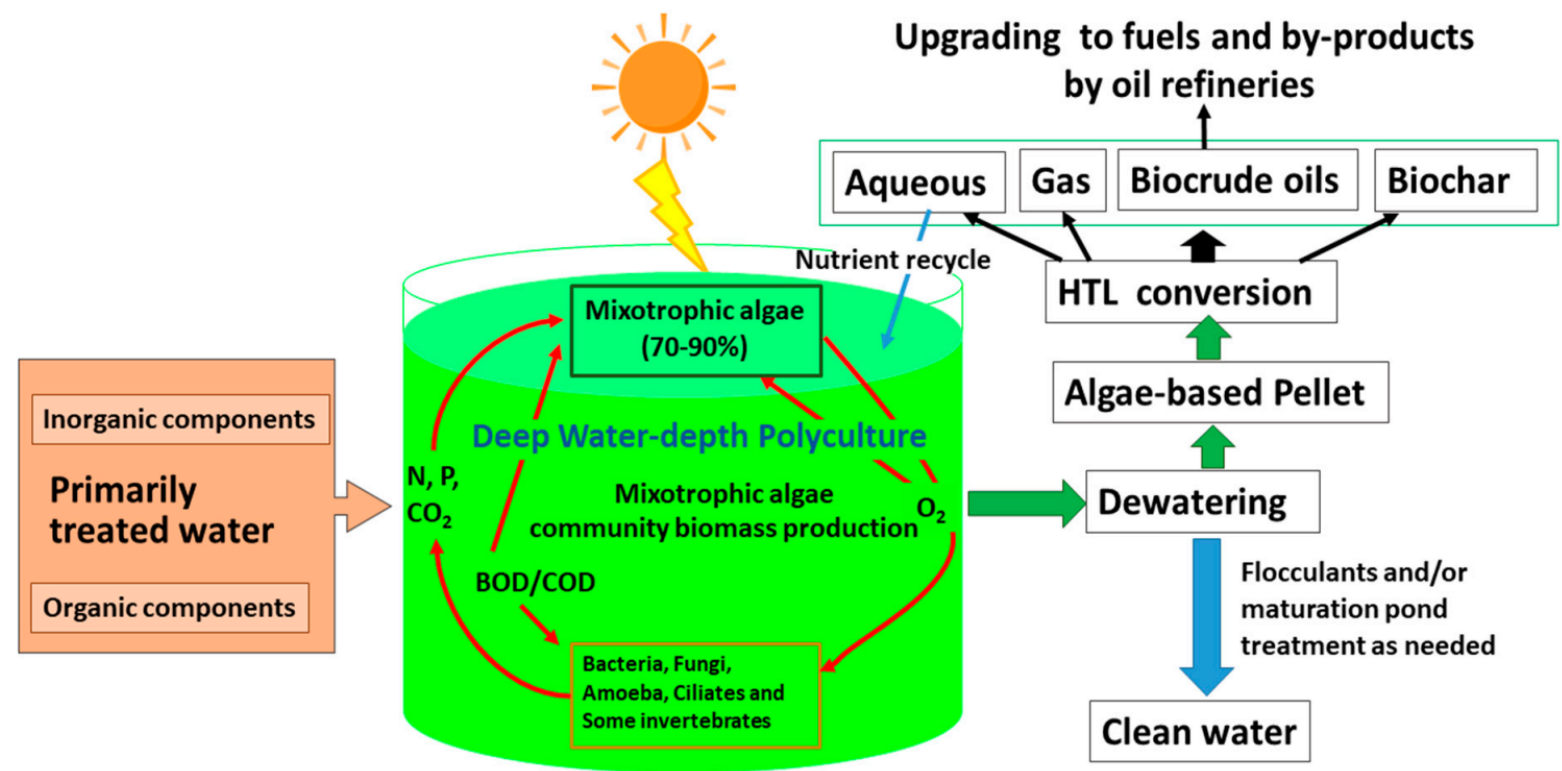

Figure 5. Diagram of biocrude oil production by deep-depth polyculture integrating mixotrophic algae community biomass production and wastewater treatment.

\section{Future Perspective}

As mentioned in the Introduction section, the overall economics for the HTL algal pathway are more strongly influenced by improvements in algae biomass productivity [24] Therefore, it is essential to secure stable and high algal biomass production for the efficient production of HTL biocrude oil. Deep water-depth polyculture of mixotrophic algae combined with wastewater treatment processing is the most promising way to fulfil this requirement.

It is worth noting that there are multiple approaches for selecting productive polycultures, ranging from synthetic polycultures using carefully selected laboratory strains to naturally occurring polycultures, as shown in Table 3. In the study of Demura et al. [14], the deep water-depth polyculture of mixotrophic algae was composed of native mixotrophic algae population. Thomas et al. [81] provided evidence that the native polyculture maintained higher diversity than the synthetic polyculture, enhancing the biomass productivity and nutrient removal. The differences became more pronounced under the grazing and resource stress conditions. However, they also suggested that the results should be interpreted as those of one pilot-scale empirical example; they could not infer whether natural or synthetic polycultures perform better in general. Various types of synthetic mixotrophic algae polycultures with functional complementarity should be constructed and tested on their capacities from various ecological aspects against native mixotrophic algae polycultures. This will be required for selecting more appropriate mixotrophic polycultures for biocrude-oil production.

Author Contributions: Writing-Sections 1-3, 7 and 8, and editing, M.M.W.; Writing-Sections 4-6, A.I. All authors have read and agreed to the published version of the manuscript.

Funding: This work was supported by “Next Generation Renewable Energy Technology Development Project" of Fukushima Prefecture, Japan (FY2013-FY2015), "R\&D Project for Biofuel Production Using Algae" of Agency for Natural Resources and Energy, Ministry of Economy, Trade, and Industry, Japan (FY2016-FY2018), and “Low Carbon Technology Research, Development and Demonstration 
Program" of Ministry of Environment, Japan (FY2017-FY2020), each of which was conducted as a part of "Algae Biomass Energy R\&D Program, Tsukuba International Strategic Zone" of the Cabinet Office, Japanese Government.

Institutional Review Board Statement: Not applicable.

Informed Consent Statement: Not applicable.

Data Availability Statement: Not applicable.

Conflicts of Interest: The authors declare no conflict of interest.

\section{References}

1. Chisti, Y. Biodiesel from microalgae. Biotechnol. Adv. 2007, 25, 294-306. [CrossRef] [PubMed]

2. Henry, R.J. Evaluation of plant biomass resources available for replacement of fossil oil. Plant Biotechnol. J. $2010,8,288-293$. [CrossRef] [PubMed]

3. Lundquist, T.J.; Woertz, I.C.; Quinn, N.W.T.; Benemann, J.R. A Realistic Technology and Engineering Assessment of Algae Biofuel Production; Energy Biosciences Institute, University of California: Berkeley, CA, USA, 2010.

4. Gu, X.; Martinez-Fernandez, J.S.; Pang, N.; Fu, X.; Chen, S. Recent development of hydrothermal liquefaction for algal biorefinery. Renew. Sustain. Energy Rev. 2020, 121, 109707. [CrossRef]

5. Wibawa, D.S.; Nasition, M.A.; Noguchi, R.; Ahamed, T.; Demura, M.; Watanabe, M.M. Microalgae oil production: A downstream approach to energy requirements for the Minamisoma pilot plant. Energies 2018, 11, 521. [CrossRef]

6. Sasongko, N.A.; Noguchi, R.; Ito, J.; Demura, M.; Ichikawa, S.; Nakajima, M.; Watanabe, M.M. Engineering study of a pilot scale process plant for microalgae-oil production utilizing municipal wastewater and flue gases: Fukushima pilot plant. Energies 2018, 11, 1693. [CrossRef]

7. Ishizaki, R.; Noguchi, R.; Putra, A.S.; Ichikawa, S.; Ahamed, T.; Watanabe, M.M. Reduction in energy requirement and CO2 emission for microalgae oil production using wastewater. Energies 2020, 13, 1641. [CrossRef]

8. Ishizaki, R.; Putra, A.S.; Ichikawa, S.; Ahamed, T.; Watanabe, M.M.; Noguchi, R. Microalgae oil production using wastewater in Japan-Introducing operational cost function for sustainable management of WWTP. Energies 2020, 13, 5310. [CrossRef]

9. Cui, Z.; Cheng, F.; Jarvis, J.M.; Brewer, C.E.; Jena, U. Roles of co-solvent in hydrothermal liqauefaction of low-lipid, high protein algae. Bioresour. Technol. 2020, 123454. [CrossRef]

10. Lu, J.; Zhang, Z.; Zhang, L.; Fan, G.; Wu, Y. Catalytic hydrothermal liquefaction of microalgae over different biochars. Catal. Commun. 2021, 149, 106236. [CrossRef]

11. Hamilton, C.E.; Rosmeissl, N. Exploring the Utilization of Complex Algal Communities to Address Algal Pond Crash and Increase Annual Biomass Production for Algal Biofuels; U.S. Department of Energy, Energy Efficiency \& Renewable Energy: Washington, DC, USA, 2014.

12. Lam, M.K.; Lee, K.T. Microalgae biofuels: A critical review of issues, problems and the way forward. Biotechnol. Adv. 2012, 30, 673-690. [CrossRef]

13. Dalrymple, O.K.; Halfhide, T.; Udom, I.; Gilles, B.; Wolan, J.; Zhang, Q.; Ergas, S. Wastewater use in algae production for generation of renewable resources: A review and preliminary results. Aquat. Biosyst. 2013, 9, 2. [CrossRef]

14. Demura, M.; Yoshida, M.; Yokoyama, A.; Ito, J.; Kobayashi, H.; Kayano, S.; Tamangawa, T.; Watanobe, M.; Date, N.; Osada, M.; et al. Biomass productivity of native algal communities in Minamisoma city, Fukushima Prefecture, Japan. Algal Res. 2018, 29, 22-35. [CrossRef]

15. Chen, G.; Zhao, L.; Qi, Y. Enhancing the productivity of microalgae cultivated in wastewater toward biofuel production: A critical review. Appl. Energy 2015, 137, 282-291. [CrossRef]

16. Craggs, R.; Sutherland, D.; Campbell, H. Hectare-scale demonstration of high rate algal ponds for enhanced wastewater treatment and biofuel production. J. Appl. Phycol. 2012, 24, 329-337. [CrossRef]

17. Craggs, R.J.; Lundqusit, T.J.; Benemann, J.R. Wastewater treatment and algal biofuel production. In Algae for Biofuels and Energy; Borowitzka, M.A., Moheimanii, N.R., Eds.; Springer: Dordrecht, The Netherlands, 2013; pp. 153-163.

18. Craggs, R.; Park, J.; Heubeck, S.; Sutherland, D. High rate algal pond systems for low-energy wastewater treatment, nutrient recovery and energy production. N. Z. J. Bot. 2014, 52, 60-73. [CrossRef]

19. Sutherland, D.L.; Turnbull, M.H.; Craggs, R.J. Increased pond depth improve algal productivity and nutrient removal in wastewater treatment high rate algal ponds. Water Res. 2014, 2014, 271-281. [CrossRef]

20. Mehrabadi, A.; Craggs, R.; Farid, M.M. Wastewater treatment high rate algal ponds (WWT HRAP) for low-cost biofuel producton. Bioresour. Technol. 2015, 184, 202-214. [CrossRef]

21. Sheehan, J.; Dunahay, T.; Benemann, J.; Roessler, P. A Look Back at the U.S. Department of Energy's Aquatic Species Program-Biodiesel from Algae; NERL/TP-580-24190; National Renewable Energy Laboratory: Golden, CO, USA, 1998.

22. Acién, F.G.; Gómez-Serrano, C.; Morales-Amaral, M.M.; Fernández-Sevilla, J.M.; Mollina-Grima, E. Wastewater treatment using microalgae: How realistic a contribution night it be to significant urban wastewater treatment? Appl. Microbiol. Botechnol. 2016, 100, 9013-9022. [CrossRef] 
23. Acién Fernández, F.G.; Gómez-Serrano, C.; Fernández-Sevilla, J.M. Recovery of nutrients from wastewaters using microalgae. Front. Sustain. Food Syst. 2018, 2, 59. [CrossRef]

24. Biddy, M.; Davis, R.; Jones, S.; Zhu, Y. Whole Algae Hydrothermal Liquefaction Technology Pathway; Technical Report NREL/TP-510058051, PNNL-22314; U.S. Department of Commerce National Technical Information Service: Springfield, VA, USA, 2013.

25. Isdepsky, A.; Gotoh, H.A.; Watanabe, S.; Watanabe, M.M. Extraordinarily High Areal Production of Mixotrophic Microalgae in $1.4 \mathrm{~m}$ Water-Depth Culture Tank Using Primarily-Treated Wastewater. Partly in: Annual Report of Development of Low Carbon Technologies Based on Collaboration between Efficient Productions of Algae Biomass and Their Conversions to High Performance Plastics, Low Carbon Technology Research, Development and Demonstration Program, Ministry of Environment, Tokyo Japan. 2019. Available online: https://www.env.go.jp/earth/pndanka/cpttv.funds/pdf/db/205.pdf (accessed on 22 October 2021). (In Japanese)

26. AIIC (Algae Industry Incubation Consortium Japan). Annual Report on RED Project for Biofuel Production Using Algae; Agency for Natural Resources and Energy, Ministry of Economy, Trade, and Industry (METI): Tokyo, Japan, 2019; pp. 1-140. (In Japanese)

27. AIIC (Algae Industry Incubation Consortium Japan). Annual Report on RED Project for Biofuel Production Using Indigenous Algae; Next Generation Renewable Energy Technology Development Project: Fukushima, Japan, 2016. (In Japanese)

28. Ichikawa, S.; Jain, A.; Gohara, T.; Matsumoto, S.; Aramaki, T.; Ito, J.; Noguchi, R.; Watanabe, M.M.; Nakajima, M. Continuous biocrude production from polycultured microalgae biomass using a bench-scale hydrothermal tubular reactor. In Proceedings of the 7th Conference of International Society for Applied Phycology (ISAP2020-2021 Virtual), Virtual, 14 May-13 August 2021.

29. WWAP (World Water Assessment Program). The United Nations World Water Development Report 2017, Wastewater: The Untapped Resource; UNESCO: Paris, France, 2017.

30. Sato, T.; Qadir, M.; Yamamoto, S.; Endo, T.; Zahoor, A. Global, reginal, and country level need for data on wastewater generation, treatment, and use. Agric. Water Manag. 2013, 130, 1-13. [CrossRef]

31. WWAP (World Water Assessment Program). The United Nations World Water Development Report 2012, Managing Water under Uncertainty and Risk; UNESCO: Paris, France, 2012.

32. Ministry of Land, Infrastructure, Transport and Tourism (MLIT). Survey for Formulating a Comprehensive Sewerage Development Plan. for Each Basin: Guideline and Commentary; MLIT: Tokyo, Japan, 2015. Available online: https://www.mlit.go.jp/common/00 1065300.pdf (accessed on 22 October 2021). (In Japanese)

33. Daverey, A.; Pandey, D.; Verma, P.; Verma, S.; Shah, V.; Dutta, K.; Arunachalam, K. Recent advances in energy efficient biological treatment of municipal wastewater. Bioresour. Technol. Rep. 2019, 7, 100252. [CrossRef]

34. Magill, B. Sewage Plants Overlooked Source of $\mathrm{CO}_{2}$. Researching and Reporting the Science and Impacts of Climate Change; Climate Central: Princeton, NJ, USA, 2016; Available online: https:/ / www.climatecentral.org/news/sewage-plants-overlooked-co2-source-20840 (accessed on 22 October 2021).

35. Sewage and Wastewater Management Department and National Institute for Land and Infrastructure Management, Ministry of Land, Infrastructure (MLIT), Transport and Tourism. Sewage Technology Vision. 2021. Available online: http:/ / www.nilim.go jp/lab/eag/pdf/01_r0302_ichibukaitei.pdf (accessed on 22 October 2021). (In Japanese)

36. Ministry of Land, Infrastructure, Transport and Tourism (MLIT). About Global Warming Countermeasures in the Sewerage Field. 2019. Available online: https:/ / www.mlit.go.jp/singikai/infra/kankyou/6/images/05.pdf (accessed on 22 October 2021). (In Japanese)

37. Steen, I. Phosphorus availability in the 21st century: Management of a non-renewable resource. Phosphorus Potassium 1998, 217, 25-31.

38. Ministry of Land, Infrastructure, Transport and Tourism (MLIT). Guide to the Recycling of Phosphorus in Sewerage. 2010. Available online: https:/ / www.mlit.go.jp/common/000113958.pdf (accessed on 22 October 2021). (In Japanese)

39. De-Bashan, L.E.; Bashan, Y. Recent advances in removing phosphorus from wastewater and its future use as fertilizer (1997-2003). Water Res. 2004, 38, 4222-4246. [CrossRef] [PubMed]

40. Hashizume, M.; Yoshida, M.; Demura, M.; Watanabe, M.M. Culture study on utilization of phosphite by green microalgae. J. Appl. Phycol. 2020, 32, 889-899. [CrossRef]

41. Liu, Y.-J.; Gu, J.; Liu, Y. Energy self-sufficient biological municipal wastewater reclamation: Present status, challenges and solutions forward. Bioresour. Technol. 2018, 269, 513-519. [CrossRef] [PubMed]

42. Li, L.; Kong, Z.; Xue, Y.; Wang, T.; Kato, H.; Li, Y.-Y. A comparative long-term operation using up-flow anaerobic sludge blanket (UASB) and anaerobic membrane bioreactor (AnMBR) for the upgrading of anaerobic treatment of N, N-dimethylformamidecontaining wastewater. Sci. Total Environ. 2020, 699, 134370. [CrossRef] [PubMed]

43. Yadav, G.; Shanmugam, S.; Sivaramakrishnan, R.; Kumar, D.; Mathimani, T.; Brindhadevi, K.; Pugazhendhi, A.; Rajendran, K. Mechanism and challenges behind algae as a wastewater treatment choice for bioenergy production and beyond. Fuel 2021, 285, 119093. [CrossRef]

44. Do, M.H.; Ngo, H.H.; Guo, W.S.; Liu, Y.; Chang, S.W.; Nguyen, D.D.; Nghiem, L.D.; Ni, B.J. Challenges in the application of microbial fuel cells to wastewater treatment and energy production: A mini review. Sci. Total Environ. 2018, 639, 910-920. [CrossRef]

45. Goto, Y.; Yoshida, N. Scaling up microbial fuel cells for treating swine wastewater. Water 2019, 11, 1803. [CrossRef]

46. Ma, B.; Xu, X.; Wei, Y.; Ge, C.; Peng, Y. Recent advances in controlling denitritation for achieving denitratation/anamox in mainstream wastewater treatment plants. Bioresour. Technol. 2020, 299, 122697. [CrossRef] 
47. Yoshida, M.; Tanabe, Y.; Yonezawa, N.; Watanabe, M.M. Energy innovation potential of oleaginous microalgae. Bifuels 2012, 3, 761-781. [CrossRef]

48. Carney, L.T.; Reinsch, S.S.; Lane, P.D.; Solberg, O.D.; Jansen, L.S.; Williams, K.P.; Trent, J.D.; Lane, T.W. Microbiome analysis of a microalgal mass culture growing in municipal wastewater in a prototype OMEGA photobioreactor. Algal Res. 2014, 4, 52-61. [CrossRef]

49. Plöhn, M.; Spain, O.; Sirin, S.; Silva, M.; Escudero-Oñate, C.; Ferrando-Climent, L.; Allahverdiyeva, Y.; Funk, C. Wastewater treatment by microalgae. Physiol. Plant. 2021, 172, 568-578. [CrossRef]

50. Bohutskyi, P.; Spiering, R.E.; Phan, D.; Kopachevsky, A.M.; Tang, Y.; Betenbaugh, M.J.; Bouwer, E.J.; Lundquist, T.J. Bioenergy from wastewater resurces: Nutrine removal, productivity and sttleabilitynof indigenous algal-bacteria polyculture, an effect of biomass composition variability on methane production kinetics and anaerobic digestion energy balance. Algal. Res. 2018, 36, 217-228. [CrossRef]

51. Zhang, T.-U.; Wu, Y.-H.; Zhuang, L.-L.; Wang, X.-X.; Hu, H.-Y. Screening heterotrophic microalgal strains by using the Biolog method for biofuel production from organic wastewater. Algal Res. 2014, 6, 175-179.

52. Godrijan, J.; Drapeau, D.; Balch, W.M. Mixotrophc uptake of organic compounds by coccolithophores. Limnol. Oceanogr. 2020, 65, 1410-1421. [CrossRef]

53. Girard, J.-M.; Roy, M.-L.; Hafsa, M.B.; Gagnon, J.; Faucheux, N.; Heitz, M.; Tremblay, R.; Deschênes, J.-S. Mixotrophic cultivation of green microalgae Scenedesmus obliquus on cheese whey permeate for biodiesel production. Algal Res. 2014, 5, 241-248. [CrossRef]

54. Ji, Y.; Hu, W.; Li, X.; Ma, G.; Song, M.; Pei, H. Mixotrophic growth and biochemical analysis of Chlorella vulgaris cultivated with diluted monosodium glutamate wastewater. Bioresour. Technol. 2014, 152, 471-476. [CrossRef]

55. Park, W.-K.; Moon, M.; Kwak, M.-S.; Jeon, S.; Choi, G.-G.; Yang, J.-W.; Lee, B. Use of orange peel extract for mixotrophic cultivation of Chlorella vulgaris: Increased production of biomass and FAMEs. Bioresour. Technol. 2014, 171, 343-349. [CrossRef]

56. Moreno-Garcia, L.; Adjallé, K.; Barnabé, S.; Raghavan, G.S.V. Microalgae biomass production for a biorefinery system: Recent advances and the way toward sustainability. Renew. Sustain. Energy Rev. 2017, 76, 493-506. [CrossRef]

57. Villarejo, A.; Orús, M.I.; Martínez, F. Coordination of photosynthetic and respiratory metabolism in Chlorella vulgaris UAM 101 in the light. Physiol. Plant. 1995, 94, 680-686. [CrossRef]

58. Liang, Y.; Sarkany, N.; Cui, Y. Biomass and lipid productivities of Chlorella vulgaris under autotrophic, heterotrophic and mixotrophic growth conditions. Biotechnol. Lett. 2009, 31, 1043-1049. [CrossRef]

59. Perez-Garcia, O.; Escalante, F.M.E.; de-Bashan, L.E.; Bashan, Y. Heterotrophic cultures of microalgae: Metabolism and potential products. Water Res. 2011, 45, 11-36. [CrossRef]

60. Davis, R.; Markham, J.N.; Kinchin, C.M.; Canter, C.; Han, J.; Li, Q.; Coleman, A.; Wigmosta, M.; Zhu, Y. 2017 Algae Harmonization Study: Evaluating the Potential for Future Algal Biofuel Costs, Sustainability, and Resource Assessment from Harmonized Modeling; Technical Report ANL-18/12; NREL/TP-5100-70715; PNNL-27547; National Renewable Energy Laboratory: Golden, CO, USA, 2018.

61. Tilman, D. The ecological consequences of changes in biodiversity: A search for general principles. Ecology 1999, 80, 1455-1474. [CrossRef]

62. Dzialowski, A.R.; Smith, V.H. Nutrient dependent effects of consumer identity and diversity on freshwater ecosystem function. Freshw. Biol. 2008, 53, 148-158. [CrossRef]

63. Zeller, S.L.; Kalinina, O.; Flynn, D.F.B.; Schmid, B. Mixtures of genetically modified wheat lines outperform monocultures. Ecol. Appl. 2012, 22, 1817-1826. [CrossRef]

64. Cardinale, B.J.; Gross, K.; Fritschie, K.; Flombaum, P.; Fox, J.W.; Rixen, C.; van Ruijven, J.; Reich, P.B.; Scherer-Lorenzen, M.; Wilsey, B.J. Biodiversity simultaneously enhances the production and stability of community biomass, but the effects are independent. Ecology 2013, 94, 1697-1707. [CrossRef]

65. Hulot, F.D.; Lacroix, G.; Lescher-Moutoué, F.; Loreau, M. Functional diversity governs ecosystem response to nutrient enrichment. Nature 2000, 405, 340-344. [CrossRef]

66. Worm, B.; Lotze, H.K.; Hillebrand, H.; Sommer, U. Consumer versus resource control of species diversity and ecosystem functioning, Nature 2002, 417, 848-851. Nature 2002, 417, 848-851. [CrossRef]

67. Norberg, J. Biodiversity and ecosystem functioning: A complex adaptive systems approach. Limnol. Oceanogr. 2004, 49, 1269-1277. [CrossRef]

68. Tylianakis, J.M.; Rand, T.A.; Kahmen, A.; Klein, A.-M.; Buchmann, N.; Perner, J.; Tscharntke, T. Resource heterogeneity moderates the biodiversity-function relationship in real world ecosystems. PLoS Biol. 2008, 6, e122. [CrossRef]

69. Behl, S.; de Schryver, V.; Diehl, S.; Stibor, H. Trophic transfer of biodiversity effects: Functional equivalence of prey diversity and enrichment? Ecol. Evol. 2012, 2, 3110-3122. [CrossRef] [PubMed]

70. Novoveská, L.; Zaparta, A.K.M.; Zabolotney, J.B.; Atwood, M.C.; Sundstrom, E.R. Optimizing microalgae cultivation and wastewater treatment in large-scale offshore photobioreactors. Algal Res. 2016, 2016, 85-94. [CrossRef]

71. Narwani, A.; Lashaway, A.R.; Hietala, D.C.; Savage, P.E.; Cardinale, B.J. Power of plankton: Effect of algal biodiversity on biocrude production and stability. Environ. Sci. Technol. 2016, 50, 13142-13150. [CrossRef]

72. Hietala, D.C.; Koss, C.K.; Narwani, A.; Lashaway, A.R.; Godwin, C.M.; Cardinale, B.J.; Savage, P.E. Influence of biodiversity, biochemical composition, and species identity on the quality of biomass and biocrude oil produced via hydrothermal liquefaction. Algal Res. 2017, 26, 203-217. [CrossRef] 
73. Godwin, C.M.; Hietala, D.C.; Lashaway, A.R.; Narwani, A.; Savage, P.E.; Cardinal, B.J. Ecological stoichiometry meets ecological engineering: Using polycultures to enhance the multifunctionality of algal biocrude system. Environ. Sci. Technol. 2017, 51, 11450-11458. [CrossRef]

74. Godwin, C.M.; Lashaway, A.R.; Hietala, D.C.; Savage, P.E.; Cardinal, B.J. Biodiversity improves the ecological design of sustainable biofuel systems. GCB Bioenergy 2018, 10, 752-765. [CrossRef]

75. Carruthers, D.N.; Godwin, C.M.; Hietala, D.C.; Cardinal, B.J.; Lin, X.N.; Savage, P.E. Biodiversity improves life cycle sustainability metrics in algal biofuel production. Environ. Sci. Technol. 2019, 53, 9279-9288. [CrossRef]

76. Chen, W.-T.; Zhang, Y.; Zhang, J.; Yu, G.; Schdeman, L.C.; Zhang, P.; Minarick, M. Hydrothermal liquefaction of mixed-culture algal biomass from wastewater treatment system into bio-crude oil. Bioresour. Technol. 2014, 152, 130-139. [CrossRef]

77. Thomas, P.K.; Dunn, G.P.; Coats, E.R.; Newby, D.T.; Feris, K.P. Algal diversity and traits predict biomass yield and grazing resistance in wastewater cultivation. J. Appl. Phycol. 2019, 31, 2323-2334. [CrossRef]

78. Kim, B.-H.; Choi, J.-E.; Cho, K.; Kang, Z.; Ramanan, R.; Moon, D.-G.; Kim, H.-S. Influence of water depth on microalgal production, biomass harvest, and energy consumption in high rate algal pond using municipal wastewater. J. Microbiol. Biotechnol. 2018, 28, 630-637. [CrossRef]

79. Audu, M.; Myint, M.T.; Cheng, F.; Mallick, K.; Jena, U.; Nirmalakhandan, N.; Brewer, C.E. Hydrothermal liquefaction of algae grown on brackish dairy wastewater. In Proceedings of the ASABE 2018 Annual International Meeting, Detroit, MI, USA, 29 July-1 August 2018. [CrossRef]

80. Podkuiko, L.; Kasemets, M.-L.; Kikas, T.; Lips, I. Cultivation of algae polyculture in municipal wastewater with CO2 supply. Environ. Clim. Technol. 2020, 24, 188-200. [CrossRef]

81. Thomas, P.K.; Dunn, G.P.; Good, A.R.; Callahan, M.P.; Coats, E.R.; Newby, D.T.; Feris, K.P. A natural algal polyculture outperforms an assembled polyculture in wastewater-based open pond biofuel production. Algal Res. 2019, 40, 101488. [CrossRef]

82. Arashiro, L.T.; Ferrer, I.; Rousseau, D.P.L.; van Hulle, S.W.H.; Garfí, M. The effect of primary treatment of wastewater in high rate algal pond systems: Biomass and bioenergy recovery. Bioresour. Technol. 2019, 280, 27-36. [CrossRef]

83. Goswami, G.; Makut, B.B.; Das, D. Sustainable production of bio-crude oil via hydrothermal liquefaction of symbiotically grown biomass of microalgae-bacteria coupled with effective wastewater treatment. Sci. Rep. 2019, 9, 15016. [CrossRef]

84. Liu, J.; Danneels, B.; Vanormelingen, P.; Vyverman, W. Nutrient removal form horticultural wastewater by benthic filamentous algae Klebsormidium sp., Stigeoclonium spp. and their communities: From laboratory flask to outdoor Algal Turf Scrubber (ATS). Water Res. 2016, 92, 61-68. [CrossRef]

85. Ryšánek, D.; Elster, J.; Kováčik, L.; Škaloud, P. Diversity and dispersal capacities of a terrestrial algal genus Klebsormidium (Streptophyta) in polar regions. FEMS Micobiol. Ecol. 2016, 92, fiw039. [CrossRef]

86. Molina Grima, E.; Femández Sevilla, J.M.; Sánchez Pérez, J.A.; García Camacho, F. A study on simultaneous photolimitation and photoinhibition in dense microalgal cultures taking into account incident and averaged irradiances. J. Biotechnol. 1996, 45, 59-69. [CrossRef]

87. Benemann, J. Wastewater treatment with microalgae ponds. In Proceedings of the 7th Conference of International Society for Applied Phycology (ISAP2020-2021 Virtual), Virtual, 14 May-13 August 2021.

88. Lundquist, T.J.; Blackwell, P.E.S.; Diego, E.; Coyne, J.; Benemann, J. Microalgae for water and nutrient recycling. In Proceedings of the 7th Conference of International Society for Applied Phycology (ISAP2020-2021 Virtual), Virtual, 14 May-13 August 2021.

89. Craggs, R.J.; Park, J.B.K.; Weaver, L. Removal of faecal indicators and human viral pathogens in hectare-scale wastewater treatment high rate algal pond system. In Proceedings of the 7th Conference of International Society for Applied Phycology (ISAP2020-2021 Virtual), Virtual, 14 May-13 August 2021.

90. Acién, F.G. Microalgae production coupled to wastewater treatment. In Proceedings of the 7th Conference of International Society for Applied Phycology (ISAP2020-2021 Virtual), Virtual, 14 May-13 August 2021.

91. Sun, L.; Tian, Y.; Zhang, J.; Cui, H.; Zuo, W.; Li, J. A novel symbiotic system combining algae and sludge membrane bioreactor technology for wastewater treatment and membrane fouling mitigation: Performance and mechanism. Chem. Eng. J. 2018, 344, 246-253. [CrossRef]

92. Ye, J.; Liang, J.; Wang, L.; Markou, G.; Jia, Q. Operation optimization of a photo-sequencing batch reactor for wastewater treatment: Study on influencing factors and impact on symbiotic microbial ecology. Bioresour.Technol. 2018, 252, 7-13. [CrossRef]

93. Sun, L.; Tian, Y.; Zhang, J.; Li, H.; Tang, C.; Li, J. Wastewater treatment and membrane fouling with algae-activated sludge culture in a novel membrane bioreactor: Influence of inoculation ratios. Chem. Eng. J. 2018, 343, 455-459. [CrossRef]

94. Tang, C.-C.; Tian, Y.; He, Z.-W.; Zuo, W.; Zhang, J. Performance and mechanism of a novel algal-bacterial symbiosis system based on sequencing catch suspended biofilm reactor treating domestic wastewater. Bioresour. Technol. 2018, 265, 422-431. [CrossRef]

95. Mujtaba, G.; Rizwan, M.; Kim, G.; Lee, K. Removal of nutrients and COD through co-culturing activated sludge and immobilized Chlorella vulgaris. Chem. Eng. J. 2018, 343, 155-162. [CrossRef]

96. Zhu, S.; Qin, L.; Feng, P.; Shang, C.; Wang, Z.; Yuan, Z. Treatment of low C/N ratio wastewater and biomass production using co-culture of Chlorella vulgaris and activated sludge in a batch photobioreactor. Bioresour. Technol. 2019, 274, 313-320. [CrossRef]

97. Sepehri, A.; Sarrafzadeh, M.-H.; Avateffazeli, M. Interaction between Chlorella vulgaris and nitrifying-enriched activated sludge in the treatment of wastewater with low C/N ratio. J. Clean. Prod. 2020, 247, 119164. [CrossRef]

98. Fan, J.; Chen, Y.; Zhang, T.C.; Ji, B.; Gao, L. Performance of Chlorella sorokiniana-activated sludge consortium treating wastewater under light-limited heterotrophic condition. Chem. Eng. J. 2020, 382, 122799. [CrossRef] 
99. Nugyen, T.-T.-D.; Niguyen, T.-T.; Binh, Q.A.; Bui, X.-T.; Ngo, H.H.; Vo, H.N.P.; Lin, K.-Y.A.; Vo, T.-D.-H.; Guo, W.; Lin, C.; et al. Co-culture of microalgae-activated sludge for wastewater treatment and biomass production: Exploring their role under different inoculation ratios. Bioresour. Technol. 2020, 314, 123754. [CrossRef]

100. Randall, H. NMSU Environmental Engineers Examine New Method for Wasterwater Treatment, Reuse. 2019. Available online: https:/ / ce.nmsu.edu/nmsu-environmental-engineers-examine-new-method-for-wastewater-treatment-reuse/ (accessed on 21 October 2021)

101. Brennan, L.; Owende, P. Biofuels from microalgae-a review of technologies for production, processing, and extractions of biofuels and co-products. Renew. Sustain. Energy Rev. 2010, 14, 557-577. [CrossRef]

102. Mohn, F.H. Experiences and strategies in the recovery of biomass from mass cultures of microalgae. In Algae Biomass, Production and Use; Shelef, G., Soeder, C.J., Eds.; Elsevier/North-Holland Biomedical Press: Amsterdam, The Netherlands, 1980 ; pp. 547-571.

103. Uduman, N.; Qi, Y.; Danquah, M.K.; Forde, G.M.; Hoadley, A. Dewatering of microalgal cultures: A major bottleneck to algae-based fuels. J. Renew. Sustain. Energy 2010, 2, 012701. [CrossRef]

104. Fasaei, F.; Bitter, J.H.; Slegers, P.M.; van Boxtel, A.J.B. Techno-economic evaluation of microalgae harvesting and dewatering systems. Algal Res. 2018, 31, 347-362. [CrossRef]

105. Pahl, S.L.; Lee, A.K.; Kalaitzidis, T.; Ashman, P.J.; Sathe, S.; Lewis, D.M. Harvesting, Thickening and Dewatering Microalgae Biomass. In Algae for Biofuels and Energy; Borowitzka, M.A., Moheimani, N.R., Eds.; Springer: Dordrecht, The Netherlands, 2013; pp. 165-185.

106. Grima, E.M.; Belarbi, E.H.; Fernandez, F.G.A.; Medina, A.R.; Chisti, Y. Recovery of microalgal biomass and metabolites: Process options and economics. Biotechnol. Adv. 2003, 20, 491-515. [CrossRef]

107. Danquah, M.K.; Ang, L.; Uduman, N.; Moheimani, N.; Fordea, G.M. Dewatering of microalgal culture for biodiesel production: Exploring polymer flocculation and tangential flow filtration. J. Chem. Technol. Biotechnol. 2009, 84, 1078-1083. [CrossRef]

108. Shelef, G.; Sukenik, A.; Green, M. Microalgae Harvesting and Processing: A Literature Review; Report SERI/STR-231-2396; Technion Research and Development Foundation Ltd.: Haifa, Israel, 1984. Available online: https://www.nrel.gov/docs/legosti/old/23 96.pdf (accessed on 22 October 2021).

109. Becker, E.W.; Venkataraman, L.V. Biotechnology and Exploitation of Algae: The Indian Approach: A Comprehensive Report on the Cultivation and Utilization of Microalgae Performed at the Central Food Technological Research Institute, Mysore, India; German Agency for Technical Cooperation: Eschborn, Germany, 1982.

110. O'Connell, D.; Savelski, M.; Slater, C.S. Life cycle assessment of dewatering routes for algae derived biodiesel processes. Clean Technol. Environ. Policy 2013, 15, 567-577. [CrossRef]

111. Lardon, L.; Hélias, A.; Sialve, B.; Steyer, J.-P.; Bernard, O. Life-cycle assessment of biodiesel production from microalgae. Environ. Sci. Technol. 2009, 43, 6475-6481. [CrossRef]

112. Shelef, G.; Soeder, C.J. (Eds.) Algae Biomass, Production and Use; Elsevier/North Holland Biomedical Press: Amsterdam, The Netherlands, 1980.

113. Burlew, J.S. (Ed.) Current status of the large-scale culture of Algae 1. In Algal Culture from Laboratory to Pilot Plant; Carnegie Institution of Washington Publication: Washington, DC, USA, 1953; pp. 3-23.

114. Muylaert, K.; Bastiaens, L.; Vandamme, D.; Gouveia, L. Harvesting of microalgae: Overview of process options and their strengths and drawbacks. In Microalgae-based Biofuels and Bioproducts; Gonzalez-Fernandez, C., Muñoz, R., Eds.; Woodhead Publishing: Oxford, UK, 2017; pp. 113-132.

115. Singh, G.; Patidar, S.K. Microalgae Harvesting Techniques: A review. J. Environ. Manage. 2018, 217, 499-508. [CrossRef]

116. Richmond, A. (Ed.) Biological principles of mass cultivation. In Handbook of Microalgal Culture: Biotechnology and Applied Phycology; Blackwell Publishing: Oxford, UK, 2003; pp. 125-177.

117. Moraine, R.; Shelef, G.; Sandbank, E.; Bahr-Moshe, Z.; Shvartzburd, L. Recovery of sewage-borne algae: Flocculation, flotation, and centrifugation techniques. In Algae Biomass, Production and Use; Shelef, G., Soeder, C.J., Eds.; Elsevier/North-Holland Biomedical Press: Amsterdam, The Netherlands, 1980; pp. 531-545.

118. Tenney, M.W.; Echelberger, W.F.; Schuessler, R.G.; Pavoni, J.L. Algal flocculation with synthetic organic polyelectrolytes. Appl. Microbiol. 1969, 18, 965-971. [CrossRef]

119. Tilton, R.C.; Murphy, L.; Dixon, J.K. Flocculation of algae with synthetic polymeric flocculants. Water Res. 1972, 6, 155-164. [CrossRef]

120. Bilanovic, D.; Shelef, G.; Sukenik, A. Flocculation of microalgae with cationic polymers—Effects of medium salinity. Biomass 1988, 17, 65-76. [CrossRef]

121. Udom, I.; Zaribaf, B.H.; Halfhide, T.; Gillie, B.; Dalrymple, O.; Zhang, Q.; Ergas, S.J. Harvesting microalgae grown on wastewater. Bioresour. Technol. 2013, 139, 101-106. [CrossRef]

122. Molina Grima, E.; Acien Fernandez, F.G.; Robles Medina, A. Downstream processing of cell-mass and products. In Handbook of Microalgal Culture: Biotechnology and Applied Phycology; Richmond, A., Ed.; Blackwell Publishing: Oxford, UK, 2003; pp. 215-251.

123. Mohn, F.H.; Soeder, C.J. Improved technologies for the harvesting and processing of microalgae and their impact on production costs. Arch. Hydrobiol. Bech. Ergebn. Limnol. 1978, 11, 228-253.

124. Biller, P.; Ross, A. Potential yields and properties of oil from the hydrothermal liquefaction of microalgae with different biochemical content. Bioresour. Technol. 2011, 102, 215-225. [CrossRef] 
125. Jazrawi, C.; Biller, P.; Ross, A.B.; Montoya, A.; Maschmeyer, T.; Haynes, B.S. Pilot Plant Testing of Continuous Hydrothermal Liquefaction of Microalgae. Algal Res. 2013, 2, 268-277. [CrossRef]

126. Wang, B.; Huang, Y.; Zhang, J. Hydrothermal liquefaction of lignite, wheat straw and plastic waste in sub-critical water for oil: Product distribution. J. Anal. Appl. Pyrolysis 2014, 110, 382-389. [CrossRef]

127. Gollakota, A.R.K.; Kishore, N.; Gu, S. A review on hydrothermal liquefaction of biomass. Renew. Sustain. Energy Rev. 2018, 81, 1378-1392. [CrossRef]

128. Kumar, M.; Oyedun, A.O.; Kumar, A. A review on the current status of various hydrothermal technologies on biomass feedstock. Renew. Sustain. Energy Rev. 2018, 81, 1742-1770. [CrossRef]

129. Chen, P.H.; Quinn, J.C. Microalgae to biofuels through hydrothermal liquefaction: Open-source techno-economic analysis and life cycle assessment. Appl. Energy 2021, 289, 116613. [CrossRef]

130. Elliott, D.C. Historical developments in hydroprocessing bio-oils. Energy Fuels 2007, 21, 1792-1815. [CrossRef]

131. Jin, B.; Duan, P.; Xu, Y.; Wang, F.; Fan, Y. Co-liquefaction of micro-and macroalgae in subcritical water. Bioresour. Technol. 2013, 149, 103-110. [CrossRef]

132. Elliott, D.C.; Biller, P.; Ross, A.B.; Schmidt, A.J.; Jones, S.B. Hydrothermal liquefaction of biomass: Developments from batch to continuous process. Bioresour. Technol. 2015, 178, 147-156. [CrossRef]

133. Toor, S.S.; Rosendahl, L.; Rudolf, A. Hydrothermal liquefaction of biomass: A review of subcritical water technologies. Energy 2011, 36, 2328-2342. [CrossRef]

134. Palomino, A.; Godoy-Silva, R.D.; Raikova, S.; Chuck, C.J. The storage stability of biocrude obtained by the hydrothermal liquefaction of microalgae. Renew. Energy 2020, 145, 1720-1729. [CrossRef]

135. Zhang, L.; Li, C.J.; Zhou, D.; Zhang, S.C.; Chen, J.M. Hydrothermal liquefaction of water hyacinth: Product distribution and identification. Energy Sources A: Recovery Util. Environ. Eff. 2013, 35, 1349-1357.

136. Nallasivam, J.; Eboibi, B.E.; Isdepsky, A.; Lavanya, M.; Bhaskar, S.; Chinnasamy, S. Hydrothermal liquefaction of water hyacinth (Eichhorniacrassipes): Influence of reaction temperature on product yield, carbon and energy recovery, and hydrocarbon species distribution in biocrude. Biomass Convers. Biorefin. 2020. [CrossRef]

137. Chen, X.; Peng, X.; Ma, X.; Wang, J. Investigation of Mannich reaction during co-liquefaction of microalgae and sweet potato waste. Bioresour. Technol. 2019, 284, 286-292. [CrossRef]

138. Hietala, D.C.; Godwin, C.M.; Cardinale, B.J.; Savage, P.E. The independent and coupled effects of feedstock characteristics and reaction conditions on biocrude production by hydrothermal liquefaction. Appl. Energy 2019, 235, 714-728. [CrossRef]

139. Eboibi, B.E. Impact of time on yield and properties of biocrude during downstream processing of product mixture derived from hydrothermal liquefaction of microalga. Biomass Convers. Biorefin. 2019, 9, 379-387. [CrossRef]

140. Fortier, M.-O.P.; Roberts, G.W.; Stagg-Williams, S.M.; Sturm, B.S.M. Life cycle assessment of bio-jet fuel from hydrothermal liquefaction of microalgae. Appl. Energy 2014, 122, 73-82. [CrossRef]

141. Carneiro, M.L.N.M.; Pradelle, F.; Braga, S.L.; Gomes, M.S.P.; Martins, A.R.F.A.; Turkovics, F.; Pradelle, R.N.C. Potential of biofuels from algae: Comparison with fossil fuels, ethanol and biodiesel in Europe and Brazil through life cycle assessment (LCA). Renew. Sustain. Energy Rev. 2017, 73, 632-653. [CrossRef]

142. Frank, E.; Wang, M.; Han, J.; Elgowainy, A.; Palou-Rivera, I. Life-Cycle Analysis of Algal-Based Fuels with the GREET Model; Energy Systems Division, Argonne Laboratory: San Francisco, CA, USA, 2011.

143. Frank, E.D.; Elgowainy, A.; Han, J.; Wang, Z. Life cycle comparison of hydrothermal liquefaction and lipid extraction pathways to renewable diesel from algae. Mitig. Adapt. Strateg. Glob. Chang. 2013, 18, 137-158. [CrossRef]

144. de Boer, K.; Moheimani, N.R.; Borowitzka, M.A.; Bahri, P.A. Extraction and conversion pathways for microalgae to biodiesel: A review focused on energy consumption. J. Appl. Phycol. 2012, 24, 1681-1698. [CrossRef]

145. Flesch, A.; Beer, T.; Campbell, P.K.; Batten, D.; Grant, T. Greenhouse gas balance and algae-based biodiesel. In Algae for Biofuels and Energy; Springer: Berlin/Heidelberg, Germany, 2013; pp. 233-254.

146. Woertz, I.C.; Benemann, J.R.; Du, N.; Unnasch, S.; Mendola, D.; Mitchell, B.G.; Lundquist, T.J. Life cycle GHG emissions from microalgal biodiesel- A CA-GREET model. Environ. Sci. Technol. 2014, 48, 6060-6068. [CrossRef] [PubMed]

147. Ministry of Environment. Total Greenhouse Gas Emissions-Guidelines for Calculation Method 2017. Available online: https: //www.env.go.jp/policy/local_keikaku/data/guideline.pdf (accessed on 22 October 2021). (In Japanese)

148. Vasudevan, V.; Stratton, R.W.; Pearlson, M.N.; Jersey, G.R.; Beyene, A.G.; Weissman, J.C.; Rubino, M.; Hileman, J.I. Environmental performance of algal biofuel technology options. Environ. Sci. Technol. 2012, 46, 2451-2459. [CrossRef] [PubMed]

149. Manganaro, J.L.; Lawal, A. $\mathrm{CO}_{2}$ life-cycle assessment of the production of algae-based liquid fuel compared to crude oil to diesel. Energy Fuels. 2016, 30, 3130-3139. [CrossRef]

150. Bošnjakovíc, M.; Sinaga, N. The perspective of large-scale production of algae biodiesel. Appl. Sci. 2020, 8181. [CrossRef]

151. Tyner, W.E.; Taheripour, F.; Zhuang, Q.; Birur, D.; Baldos, U.L. Land Use Changes and Consequent $\mathrm{CO}_{2}$ Emissions due to US Corn ethanol Production: A Comprehensive Analysis; Final Report; Department of Agricultural Economics at Purdue University: Lafayette, IN, USA, 2010.

152. Liu, X.; Saydah, B.; Eranki, P.; Colosi, L.M.; Mitchell, B.G.; Rhodes, J.; Clarens, A.F. Pilot-scale data provide enhanced estimates of the life cycle energy and emissions profile of algae biofuels produced via hydrothermal liquefaction. Bioresour. Technol. 2013, 148, 163-171. [CrossRef] 
153. Yoo, G.; Park, M.S.; Yang, J.-W.; Choi, M. Lipid content in microalgae determines the quality of biocrude and Energy Return on Investment of hydrothermal liquefaction. Appl. Energy 2015, 156, 354-361. [CrossRef]

154. Mehrabadi, A.; Craggs, R.; Farid, M.M. Wastewater treatment high rate algal pond biomass for bio-crude oil production. Bioresour. Technol. 2017, 224, 255-264. [CrossRef] 